\title{
Ethnoagroforestry: integration of biocultural diversity for food sovereignty in Mexico
}

\author{
Ana Isabel Moreno-Calles ${ }^{1 *}$, Alejandro Casas $^{2}$, Alexis Daniela Rivero-Romero ${ }^{1}$, Yessica Angélica Romero-Bautista ${ }^{1}$, \\ Selene Rangel-Landa ${ }^{2}$, Roberto Alexander Fisher-Ortíz ${ }^{4}$, Fernando Alvarado-Ramos ${ }^{1}$, Mariana Vallejo-Ramos ${ }^{3}$ \\ and Dídac Santos-Fita ${ }^{5}$
}

\begin{abstract}
Background: Documenting the spectrum of ecosystem management, the roles of forestry and agricultural biodiversity, TEK, and human culture for food sovereignty, are all priority challenges for contemporary science and society. Ethnoagroforestry is a research approach that provides a theoretical framework integrating socio-ecological disciplines and TEK. We analyze in this study general types of Agroforestry Systems of México, in which peasants, small agriculturalist, and indigenous people are the main drivers of AFS and planning of landscape diversity use. We analyzed the actual and potential contribution of ethnoagroforestry for maintaining diversity of wild and domesticated plants and animals, ecosystems, and landscapes, hypothesizing that ethnoagroforestry management forms may be the basis for food sufficiency and sovereignty in Mexican communities, regions and the whole nation.

Methods: We conducted research and systematization of information on Mexican AFS, traditional agriculture, and topics related to food sovereignty from August 2011 to May 2015. We constructed the database Ethnoagroforestry based on information from our own studies, other databases, Mexican and international specialized journals in agroforestry and ethnoecology, catalogues and libraries of universities and research centers, online information, and unpublished theses. We analyzed through descriptive statistical approaches information on agroforestry systems of México including 148 reports on use of plants and 44 reports on use of animals.
\end{abstract}

Results: Maize, beans, squashes and chili peppers are staple Mesoamerican food and principal crops in ethnoagroforestry systems practiced by 21 cultural groups throughout Mexico (19 indigenous people) We recorded on average $121 \pm 108$ (SD) wild and domesticated plant species, $55 \pm 27 \%$ (SD) of them being native species; $44 \pm 23 \%$ of the plant species recorded provide food, some of them having also medicinal, firewood and fodder uses. A total of 684 animal species has been recorded (17 domestic and 667 wild species), mainly used as food (34\%).

Conclusions: Ethnoagroforestry an emergent research approach aspiring to establish bases for integrate forestry and agricultural diversity, soil, water, and cultural richness. Its main premise is that ethnoagroforestry may provide the bases for food sovereignty and sustainable ecosystem management.

Keywords: Agroforestry systems, Biodiversity management, Local food systems, Small farm agriculture, Traditional agriculture

\footnotetext{
* Correspondence: isabel_moreno@enesmorelia.unam.mx

'Escuela Nacional de Estudios Superiores Unidad Morelia (ENES), Universidad

Nacional Autónoma de México. UNAM, Campus Morelia, Antigua Carretera a

Pátzcuaro No. 8701, Col. Ex-Hacienda de San José de la Huerta, Morelia

58190, Michoacán, México

Full list of author information is available at the end of the article
}

(c) The Author(s). 2016 Open Access This article is distributed under the terms of the Creative Commons Attribution 4.0 International License (http://creativecommons.org/licenses/by/4.0/), which permits unrestricted use, distribution, and reproduction in any medium, provided you give appropriate credit to the original author(s) and the source, provide a link to the Creative Commons license, and indicate if changes were made. The Creative Commons Public Domain Dedication waiver (http://creativecommons.org/publicdomain/zero/1.0/) applies to the data made available in this article, unless otherwise stated. 


\section{Background}

The vast majority of the world's biodiversity is located in the tropics [1]; but it is known that it is dramatically decreasing as long as people of the region significantly depend on it for their subsistence [1]. Conversion of forest to agricultural areas and pasturelands for cattle grazing are among the main causes of loss of biodiversity in the World [2], although more recently mining is progressively increasing its destructive impact in great areas. The traditional, indigenous, small-scale agriculture or peasant agriculture has been pointed as one main cause of poverty and hunger in the tropics, based on misunderstanding of peasant life patters, and ideological characterizations of these systems as low productivity systems, economically inefficient, unable to self-sufficiency and responsible of environmental degradation [2, 3]. However, the majority of the farmers in the global south are smallscale producers, practicing agriculture in a high variety of forms; therefore, the traditional agriculture and the relationship with biodiversity, poverty and hunger is also highly variable [1] and it cannot be a linear cause-effect conclusion. Poverty, hunger, marginalization of peasants, environmental degradation and biodiversity loss in these regions have a history more clearly linked to colonial and neoliberal policies, mining destruction of natural resources and ecosystems, industrial models of production in agriculture, livestock, forestry, oil and mineral extraction, and predatory policies of great corporation rather than responsibility of traditional agriculture [4].

Food sovereignty has emerged as a concept counter framing the corporative food regimes, broadly defined "as the right of the nations and peoples to control their food systems, including their own food cultures, production models according with their environments, their own forms of interchange and commerce" [5]. This concept has "re-appropriate [d] the term peasant and infuse [d] it with a new positively valued content" [5]. Local, traditional, indigenous, small-scale, or peasant agriculture or agroforestry have been considered as capable to sustain ever-growing demand of agricultural products while conserving biodiversity, providing critical ecosystem services, maintaining livelihoods and food sovereignty [6, 7].

Nearly $53.4 \%$ of the Mexican people live in conditions of poverty [8], and nearly $44 \%$ belong into categories of food insecurity [9], the higher percentage of them being rural and indigenous people [10]. Paradoxically, Mexico is a megadiverse country, with high biological and human cultural diversity, as well as high agro-biodiversity and diversity of agricultural systems constructed throughout the longest history of domestication and agriculture of the New World [11]. From such ancient and diverse interactions between people and local ecosystems and biotic resources has emerged one of the highest expressions of biocultural diversity of the planet $[12,13]$. From such a context, Ethnoagroforestry has raised as a research approach looking for documenting, systematizing and understanding the brad and complex spectrum of forms of agricultural, ecosystems and landscapes management, integrated in local strategies for procuring food security and sovereignty. These strategies include the using of the wild, the whole ecosystems inside and around the agricultural plots, the species diversity of the whole system. In addition, it studies the diversity of management forms, including incipient and advanced form of management of elements of the systems [14]. In addition, the strategies include a great diversity of forms of management of biodiversity, including plants, animals, fungi and microbiota, wild, semi-domesticated or in advanced levels of domestication under diverse mechanisms of artificial selection [15, 16]. The Ethnoagroforestry approach aspires analyzing agroforestry management as part of particular human cultural contexts in which the productive systems are part of social life and economic relations. Either individuals or households, communities and cultural groups who have a leading role in directing the interactions and design or modeling the components of landscapes are all crucial for understanding the drivers of AFS [17-19].

The importance of local traditional agroforestry management of Mexico has been widely recognized [17]. However, a systematic analysis of the management experiences of Mexican agroforestry is still necessary in order to identify in a deeper detail the particular contexts where the systems can be successful and requirements for adapting and improving their use and management. Such understanding would contribute to stop the unfortunate losing of the Cinderella agroforestry systems, that is happening throughout the world. The Cinderella term makes reference to agroforestry systems unrecognized and forgotten at global level but with high relevance at regional and local scale for food production, environmental protection, conservation and recovering, and social wellbeing [20]. The process of enhancing agroforestry systems [21]. The main purpose of our review is analyzing: (1) how much biodiversity (plant and animal species richness and diversity) is maintained under ethnoagroforestry management, (2) what is the importance of such diversity for food sovereignty systems; and (3) what are the potential, challenges and limitations for integrating the ethnoagroforestry approach for achieving food sovereignty in México. We hypothesized that the ethnoagroforestry management forms may be the basis for food sufficiency and sovereignty in Mexican communities, regions and the whole nation and that the routes of technological innovation according to the contemporary social needs are identifiable and possible to be attended based on local and regional TEK and agroecology and agroforestry criteria. 


\section{Methods}

\section{Construction and use of databases}

We conducted an exhaustive search of information about, agroforestry systems, management strategies, their biodiversity conservation capacity, their components and roles in social life of people managing the systems, their economic capacity among other topics summarized in Table 1. Systematization and analysis of information reported in this study was conducted from August 2011 to May 2015, but the database is still in construction. We constructed the database Ethnoagroforestry based on i) our own researches, ii) by consulting Google Scholar, Scopus, Redialyc and SIDALC databases; iii) Mexican and international specialized journals in agroforestry, ethnoecology and traditional ecological knowledge; iv) catalogues, libraries and online available information from universities and research centers; and unpublished theses.
The keywords included in the search were: agroforestry and Mexico, agroforestry system and Mexico, traditional agroforestry system and Mexico, traditional agriculture and Mexico, trees in agricultural plots and Mexico, agroecosystem and Mexico, agroforestry practices and Mexico, hedges plants and Mexico, living fences and Mexico, small farm agriculture and Mexico with quotation marks (Table 1). Searches that are more specialized were also conducted on the regional or local names of different agroforestry systems and agroforestry practices documented in a recent review of the systems by Moreno-Calles et al. [17] in English, Spanish and original language: (1) Homegarden, "huerto familiar", calmil, ekuaro,"solar"; (2) Agroforest, "agrobosques", kuojtakiloyan, te'lom, cacaotal, "café bajo sombra", "piñal”; (3) Long Fallow Agroforestry: "roza, tumba y quema”, tlacolol, kool, "agricultura itinerante", "slash and burn agriculture", "shifting agriculture", "swidden agriculture"; (4) Arid and Semiarid Agroforestry, "sistemas agroforestales de zonas áridas", milpa-chichipera, garambullal, jiotillal, huamil, coaxustles,

Table 1 Topics analyzed in database for this research

\begin{tabular}{|c|c|}
\hline Topic & Description \\
\hline System type & $\begin{array}{l}\text { It is the classification of types of ethnoagroforestry systems in } \\
\text { relation to Moreno-Calles et al. } 2013 \text { y } 2014 \text {. }\end{array}$ \\
\hline Reference & It is the reference to the work, year and author. \\
\hline Place & $\begin{array}{l}\text { It is the place where the work was done. The information is } \\
\text { reported only when it was available in the paper }\end{array}$ \\
\hline $\begin{array}{l}\text { Cultural } \\
\text { group }\end{array}$ & $\begin{array}{l}\text { It refers to the name of the group of people originating or nam } \\
\text { that cultural group that manages the system is reported }\end{array}$ \\
\hline
\end{tabular}

\section{Types}

Homegarden, agroforest, long fallow agroforestry, arid and semiarid agroforestry, terrace agroforestry, wetland agroforestry system, agrosilvopastoral system.

Papers, book, thesis, databases.

State, municipality, town.

Mayas, nahuas, mixtecos, mixes, totonacos, triquis, mazatecos, otomies, tzeltales, teenek, chontales, popolucas, zoques, raramurís, tojolabales, tzotziles, tepehuanos, zapotecos, tlahuicas, ixcatecos, rancheros.

\begin{tabular}{|c|c|}
\hline $\begin{array}{l}\text { Climate and } \\
\text { vegetation } \\
\text { type }\end{array}$ & $\begin{array}{l}\text { Include the type of climate and associated vegetation when the } \\
\text { information was available. }\end{array}$ \\
\hline $\begin{array}{l}\text { Local or } \\
\text { gional } \\
\text { stem name }\end{array}$ & $\begin{array}{l}\text { It is the local or regionally name of ethnoagroforestry system in } \\
\text { the original or in Spanish language. }\end{array}$ \\
\hline
\end{tabular}

Species Is the number of species reported in the studies reviewed or number calculation from biodiversity inventory.

Native Is the number of species native to Mexico and the percentage of species them according to the percentage of species reported with respect to the identified native species.

Uses and The uses are reported in documents consulted and standardized benefits types according to a classification of uses for agroforestry systems in plants built

by Moreno-Calles et al. 2012 and 2013. For animal classification uses and benefits were built in this work. The benefits identified for agriculture, forestry, home economics or the environment are also reported.

Main crops It refers to the main crop or crops are reported in the work reviewed.
Climate: Arid, semiarid, subhumid, template, tropical.

Examples: kuojtakiloyan, te'lom, calmil, ekuaro, kool, tlacolol, metepantle, coaxustle, calal, chinampa, milpa-chichipera, huamil.

Local level (one community), regional level (two or more communities)

Native to México

Introduced from other country

Plants uses (17 uses): food, medicinal, ornamental, firewood, fodder, construction, crafts, fibers, toys, envelope, cosmetic, aromatic, tools, resin and latex, colorant, poison, hygiene.

Plants benefits (19 benefits): habitat or food for useful species, pest control, improving the climate, maintaining of water sources, storage crops, improving soil fertility, soil retention, shadow, windbreak, hurricane protection, fire control, attractor rain, land barter or sale, hedgerow.

Animals uses (8): food, fertilizer, aquaculture, hunting, medicinal, protection, recreative, gift. Animal benefits (7): melliferous, rituals, work, transport, polination, pest control, barter or sale.

Native maize, beans, pumpkins, coffee, cocoa, pineapple. delimitation, vegetation recovery, environmental indicator, rituals, 
"oasis", "desert garden", tajos; (5) Agroforestry Terraces, "terrazas", "semiterrazas", metepantle, "terrace agriculture", "terracing", "sloping field"; and (6) Wetland Agroforestry Systems, "sistemas de humedales", "agricultura de campos elevados", calal, chinampa, "campos drenados", "drained field", "raised field". We included records on agrosilvopastoral systems specifically for this review because economic and environmental relevance for traditional agroforestry in Mexico. In total, we collected 740 references about agroforestry systems and organized the information in the database Sistemas Agroforestales Tradicionales de México. But only 192 papers, books and theses have been collected in relation to this research. The following criteria for the inclusion of the reports in the analysis richness were also considered: i) reports by an author for the same locality, taking into account the latest report; dissertations are reported in cases in which there is no any publication about a study; ii) only papers including inventories of wealth in the main text. The documents that included inventories about plant species richness were in total 148 (Appendix 1) and 44 reporting inventories of animal species (Appendix 2). Information from these references was systematized and analyzed, including maps indicating locations of the different AFS of Mexico, which were determined from the review of documents, and crossing the information with the database of municipalities from INEGI [22]. The data processing was performed with the geographic information system Ilwis open (Fig. 1). In addition, we conducted a review of databases using the key words "food", "food security", "food sovereignty" and "local food system" and agroforestry and Mexico. Food sovereignty papers are particularly examined in the Discussion section.

\section{Diversity analysis}

Agroforestry systems and their contribution to understand the conformation of landscapes were analyzed by grouping AFS into seven categories based on the typology built by Moreno- Calles et al. [17]. The number of reports about these systems, the scale of the studies (regional or local), their geographical localization, the cultural group that manage them, the general characterization of environmental conditions, the agroforestry practices, local names, main crops cultivated, agricultural techniques, forestry management, among other issues were registered (Table 1). The studies have been separated into local (one community) and regional scale (several communities) to

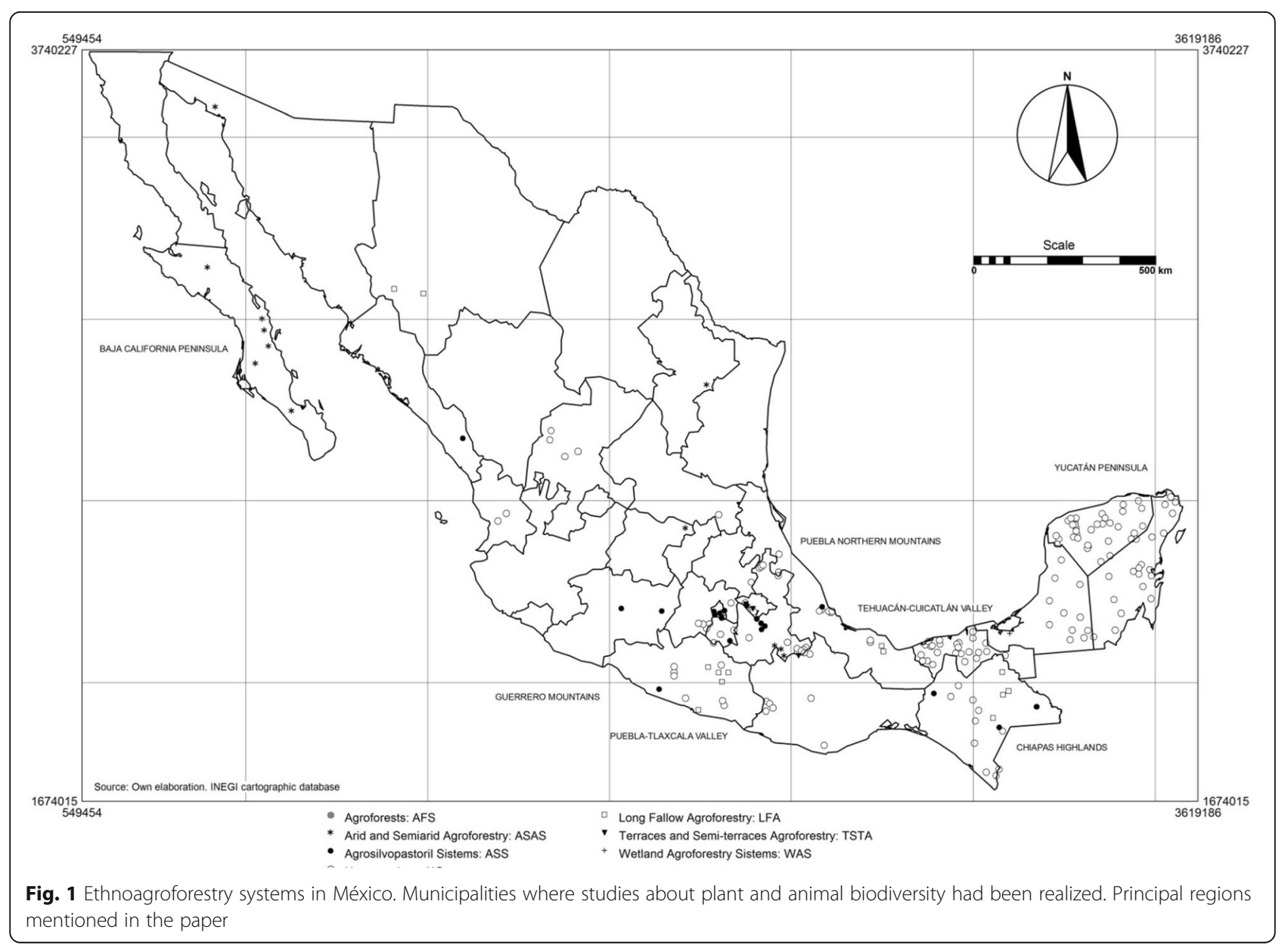


the calculation of average species richness and standard deviation.

The information about biodiversity included family and species categories, and records were included into flora and fauna databases, ecological information such as average richness of plants and animals was calculated. A classification of plants and animals' species uses and benefits was constructed by calculating species percentage used as food and other uses, mainly medicine, fuelwood, and others related with the food system.

\section{Results and discussion}

Forestry and agricultural diversity and their multiple uses and benefits

\section{Homegardens (HG)}

Integrated in this category is a great variety of agroforestry systems characterized by their multi-strata plant composition, managed intensively attached to or near the households' homes. In these systems, a high number of wild and domesticated perennial and annual plant species with different uses and often domestic animals are let standing, transplanted, cultivated and cared. Studies at global level carried out in several countries show that households practice this system for food production for subsistence or small-scale marketing and the variety of crops and wild plants provides nutritional benefits [23]. Homegarden is by far the type of agroforestry system with the largest number of studies, in Mexico as well as in the whole world [24]. In México, 95 HG studies provide good inventories of plant species maintained in there. These forms of management are reported for 20 states of the country, in temperate, tropical, subhumid, arid and semi-arid climate conditions. The plant richness is on average $122( \pm 95)$ species in local home garden studies, and $279( \pm 143)$ species in diagnoses at regional level. On average, $56 \%$ of the species recorded in the studies of homegardens are native plant species. According to the studies reporting this information, HG have mostly species uses as food $(46 \% \pm 24)$, in similar proportion with ornamental plant species. Both groups of species are destined to direct consumption (the edible ones) and spiritual satisfaction (the ornamental ones), but a small portion of products are commercialized, bartered or given as gifts to friends. Nearly $24 \%$ of the plant species recorded is used as medicine. Then, the following most common species are those used as fodder $(10 \%)$, honey producing plants, and fuel (8\%), soil retention, live fences, habitat or facilitator of valuable species and pest control $(\leq 5 \%)$. Similar results were reported by Caballero et al. [25], who documented nearly 1400 plant species occurring in Mexican HG, 572 of them (nearly 41\%) being medicinal species, 528 (37.7\%) ornamental, 442 edible (31.6\%) and $682(48.7 \%)$ plant species having other uses. Studies of HG from the Yucatán Peninsula compiled by Guido [26-28] provide relevant information about animals and plants of that region. These authors report 572 plant species with ornamental, food, medicinal and honey production, as the main uses. Among the most important studies with animal biodiversity are those by Mariaca et al. [29], who noted the wealth of wild and domesticated animals in the 200 homegardens sampled in southeastern México with an inventory of 30 species of wild and 17 domestic animals only for that region. Our review identified 13 studies recording the presence of 148 animal species, 131 of them being wild and 17 domestic. The dominant groups were birds (89 species), followed by mammals (43 species), reptiles (12 species) and insects (4 species). We recorded nearly 20 benefits provided by animals maintained in homegardens, mainly food (20\%), ornamental (17\%), recreational (17\%), pollination (9\%), raising for trading and other uses such as labor and transportation (7\%), medicinal uses, weed and pest controllers, providers of fertilizer, ritual, and protection $(>5 \%)$.

\section{Agroforests (AGF)}

These are spaces where peoples manage vegetation in order to change its composition according to their purposes and needs, preserving attributes and functions similar to those of the natural forest [30]. Some of these systems have been recorded with the name of acahuales, a term that more commonly refer to fallow areas. In several regions of Mexico, fallow areas are managed by enriching their composition with wild, weedy and even domesticated plants. AGF may be located close to the house, as a kind of variation of homegardens or may be fallow areas of slash and burn systems after cultivating maize, beans and squash. In addition, agroforests may be integrated into single management unit areas with managed acahuales and large fallow patches. Agroforests in México are complex integrated forms of landscape management and agroforestry systems where the main crops include growing species such as coffee, cocoa, pepper, vanilla, pineapple and crops of local relevance for consumption such as maize, beans, sugar cane, and citric species, among others. This form of management is recorded in the literature in eight states of Mexico, including Puebla, Oaxaca, Chiapas, Tabasco, Guerrero, Veracruz, Jalisco and Nayarit, all of them with warm and sub-humid tropical conditions and possibility the pet kot can be a type of Mayan agroforest in Yucatán and Quintana Roo linked to wild and domestic animal management [31]. Agroforests 
are the second more registered agroforestry system in the literature in Mexico (112 papers). Among the most relevant reviews about biodiversity in agroforests are those for the te'lom [32] and the kuojtakiloyan by Martínez-Alfaro et al. [33]. We reviewed 21 studies reporting plant species richness and 17 for animal species. In total, plant species richness of these systems is 1072 species and 414 animal species. This form of land management has a high percentage $(67 \%)$ of plant species native to Mexico. However, the average data describe that not all agroforests have the same contribution to the total wealth. On average, each system unit has $55( \pm 31)$ plant species and 266 $( \pm 75)$ species at regional level. The main uses and benefits of plant species includes 20 different types, among them the most important are food (53\%), medicine (18\%), firewood (12\%), timber and construction $(8 \%)$, ornamental (4\%), and other uses. For animals, 17 of the studies emphasize that wild birds are the main group (228 species), followed by mammals (90 species), insects (38 species), reptiles (30 species) and amphibians (28 species). Studies in coffee agroforests report of edible insects three species [34], but this group has been poorly studied.

\section{Long fallow agroforestry (LFA)}

These extent systems are recognized by the long fallow period in relation to the period of land cultivation and by alternating use and fallow periods [34, 35]. These systems are more commonly known by the method of thinning and clearing natural vegetation in order to make space to crops and have been named slash and burn or swidden agricultural systems. These extensive systems practice mainly rainfed agriculture, where maize, beans and squash are grown. The landscapes which are part of these systems include patches of forest, agroforests or acahuales or fallow areas used for producing coffee, pepper or sugar cane. Also common is the presence of agrosilvopastoral and homegardens systems in the agroforestry landscapes. Currently, systems of long fallow are distributed in the mountainous terrain of steep slopes of México, mainly the tropical deciduous and temperate forests of the states of Chiapas, Chihuahua, Guerrero, Jalisco, Michoacán, Morelos, Nayarit, Oaxaca, and Puebla. However, this system is also common in the flat or gentle slopes areas of the tropical forests with thin and poor calcareous soils of the Yucatán Peninsula. Local names of this system may include: tlacolol in the mountains of Guerrero [36, 37], the Maya milpa (kool) of the Yucatán Peninsula [38, 39], the mawechi of the Sierra Tarahumara [40], the coamil in Jalisco [41] and Colima [42], the huamil in the coast of Michoacán [43] and pot'kkan in Oaxaca [44] Only eight studies provide information about plant species richness. According to the average data, these systems are able to maintain on average $142 \pm 108$ species (SD). Most plant species in these systems have medicinal uses (51\%), but others are food (26\%), firewood (18\%), construction (12\%) and living fences (6\%). In three studies the authors reported that fauna in these AFS includes 46 species, mainly mammals (28 species), birds (12 species), insects (4 species) and reptiles ( 2 species), but exhaustive inventories are clearly needed. Information about the relevance of these systems for hunting and importance for food is illustrated by recent papers [45], which report that Mayan people cultivate milpa with the purpose of attracting animals for hunting. Similarity, Bernice [46] had previously documented that early secondary forests are attractive spaces for animal species valued by the Maya like the ocellated turkey, deer and peccary.

\section{Arid and semiarid agroforestry (ASAS)}

Arid and semiarid areas are characterized by a high risk and uncertainty of agriculture and other productive activities [7]. Management of soil, water, and vegetation cover has been important in the development of sustainable agroforestry systems. These areas are described as semi-intensive agroforestry systems mainly settled on slopes of rocky areas dominated by prickly pears forests, the huamil in the Valley of Santiago, Guanajuato [47, 48]. Also, in landscapes with terraces dominated by species of maguey (mainly Agave salmiana), created on the slopes and foot slopes of Valley of Mezquital, Hidalgo [7], in cacti and izotal forests in the Tehuacán Valley [49-51]. These forms of management may also have carried out in conditions of seasonal access to water, as it is the case of natural or created areas adjacent to rivers [52] and in the ravines. In alluvial areas, people have of created complex systems terraces locally called coaxustles in the Tehuacan Valley, and tajos on the banks of the rivers of the Sierra Gorda, at Xichú, Guanajuato [53]. Some of these systems can also occur under conditions of permanent access to water like the development and establishment of agroforestry oases in Baja California [54] and the desert gardens in San Luis Potosi [55]. Also relevant are the homegardens under semiarid conditions of the Tehuacan Valley [56]. These are the systems with the least number of reports recorded in the literature in arid and semi-arid AFS in seven states of México (23 papers), only nine of them providing information about species richness and uses. These studies have emphasized different life forms (trees/shrubs/herbs), but sample sizes and methods are different and difficult to compare. However, it is possible to identify that in 
arid and semiarid agroforestry systems people maintain on average $69 \pm 33$ species of plants (SD), $71 \%$ of them native species and in regional reports are 90 $( \pm 38)$ species. In almost all these systems, maize is the main crop in combination with beans, squashes, chili peppers and other edible species like peanuts, watermelon, melon, tomatoes and amaranth. However, it can be identified that as there is greater availability and access to water, people prefer to cultivate introduced species for commercialization, decreasing the percentage of native species present in agroforestry systems and those used for direct consumption. Plant species present in the form of managed are used as food, mainly for the production of edible fruit and flowers (35\%); fruits are consumed fresh, in jams, liqueurs, nuts and even are exchanged or sold for obtaining other resources, whether in the community or in regional markets [57]. Other uses include fodder (25\%), shade (17\%), firewood (16\%), and as retainers of soil and water as well as borders and living fences $(15 \%)$, ornamental $(12 \%)$ and wood (10\%). Minor uses include ceremonial, handcrafts, habitat for edible animals, stock, alcoholic drinks $(\geq 5 \%)$. Wildlife studies are still scarce, and those available recorded 97 species, mainly birds (78 species), wild mammals (14 species) and insects (5 species). The principal uses include food (9 species), pollination (6 species) and ritual (3 species). There are very important edible species of insects that have been documented in ethnoentomological studies in semi-arid areas. Edible insects are generally reported to be in interaction with trees, shrubs, prickly pears, cacti and agaves which are tolerated, encouraged, protected and cultivated in agroforestry systems mainly in order to favor the availability of edible insects, particularly larvae of Lepidoptera, Hymenoptera and adult Hemiptera [58]. Host plants of edible insects are deliberately managed in AFS in order to get these resources for direct consumption in households or for trading them.

\section{Terraces and semi-terraces agroforestry (TSTA)}

Actions to maintain soil fertility, moisture and to decrease the effect of frost on agricultural systems are common concerns for farmers and one way to achieve it is the construction of terraces $[59,60]$. However, it is important to notice that not all terraces are agroforestry systems, because only some of them include the management of wild and domestic components on the terrace borders or walls, either as a way of strengthening the terrace or because of other uses of the species. In these forms of management that are located mainly under temperate and semi-arid conditions, maize, beans and squash as main crops are grown, although recently in temperate zones people are growing alfalfa, potatoes, barley and other crops. We reviewed 25 papers documenting this system, but only four of them provide information on plant species richness and use. The average number of species recorded is $51 \pm 42$ species. (SD) The principal uses include medicine (40\%), food (19\%), firewood (20\%), soil and water control $(25 \%)$, handcraft, ritual and fodder $(\geq 5 \%)$. Among the species most commonly used in terraces of temperate zones are prickly pears, used for consumption of cladodes, fruits and edible seeds and several species of the genus Agave, which are valued for producing the sweet sap aguamiel and the fermented sap called pulque [59, 61-64].

\section{Wetland agroforestry systems}

These are systems in which the soil is raised above the water level, using materials such as mud, organic matter, trees, clusters of vegetation among others materials, in order to stabilize a portion of land as a kind of isle. Water is drained by channels and such systems are known in the literature as raised-field or drained agricultural fields [65]. Few of them remain active in México, the best known are the called chinampas of the Valley of México, the ridges or calales in the southwest of Tlaxcala [66] and the camellones chontales in Tabasco [67]. These systems have been of great academic interest since they are considered the most intensive systems of ancient México that currently persist. These agroforestry systems are extraordinarily fertile and productive due to the soils rich in organic matter, which allow them to nourish a high density and variety of crops that have been able to sustain large human populations [68]. The number of reports recording this management form is 51, but only six of them provide information on the wild and domestic diversity, most of the works have emphasized agricultural diversity. The average plant species recorded is $56 \pm 44.20$ species (SD), the main uses of these species are food (54\%), ornamental (43\%), handicraft (24\%), fertilizer (24\%), living fence (11\%), and windbreak (8\%). The main crops for human consumption are vegetables, aromatic herbs, fruit trees and to a lesser extent legumes and grains [68]. Several species of aquatic plants are exploited for human consumption [66]. Only four papers provide information about animals, which record 89 animal species, mainly fishes (32 species), birds (25 species), reptiles (13 species), malacostracans (8 species), mammals (5 species), amphibians (3 species), chondrichthyans (1 species), gastropods and other mollusks (2 species). The $63 \%$ of the species recorded are used as food. 


\section{Agrosilvopastoral systems (ASPS)}

Although presence of domestic animals is a general feature of peasant systems, there are ways of handling systems that are explicitly pastoral where the animal component is central in the management purposes, and these are integrated parts of agricultural and silvicultural management. This agroforestry system type is common in temperate, tropical and semiarid zones. We reviewed 15 studies conducted in Mestizo, Tzotzil and Zoque localities of Chiapas, Colima, Puebla, Sinaloa, Michoacán, México City, and Veracruz. All of them make explicit reference to domestic animals managed and the potential management of wild animals such as deer as alternative productive system. Although only five studies provide information on the species, and only for three case studies, species distributed in ASPS were specified. Animals commonly registered in this form of management include cattle, sheep, goats, donkeys, horses and mules, raised as source of food, power and fertilizer for agricultural activities and funding for emergencies. The vast majority of systems besides the animals' handle crops such as maize, coffee, beans, squash, citrus, oats, sorghum, and grasses. Although no systematic inventories of plants were reported in any of these papers, we identified 44 plant species recorded in these systems. Most of the species mentioned are live fences, fodder, food, firewood, medicinal uses, and shadow for cattle.

\section{Potential ethnoagroforestry contribution to food sovereignty}

\section{Biocultural and ecological contribution}

According to our review, traditional agroforestry systems (Fig. 2) differ in their contribution to the maintenance of

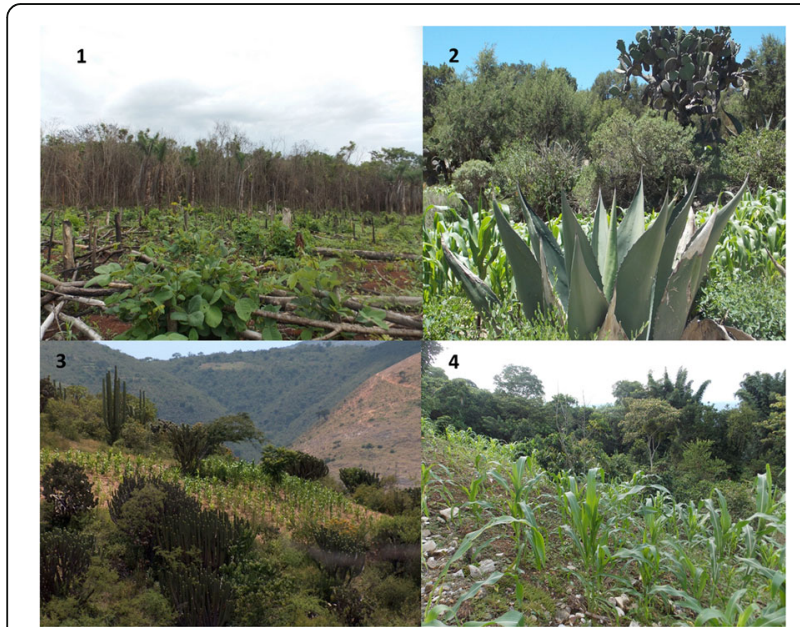

Fig. 2 Agroforestry System in México. 1) Long fallow agroforestry; 2) Terrace agroforestry; 3) Semiarid agroforestry; 4) Agroforest and milpa plant diversity and wildlife and domestic animals. It is still difficult to establish generalizations, since the contexts, purposes, plot and sample sizes evaluated were different among the systematized studies, however it is possible to identify some general patterns. It is possible to estimate that the 148 records of ethnoagroforestry systems reviewed maintain on average $121 \pm 108$ (SD) wild and domesticated plant species and $55 \pm 27 \%$ (SD) of them are on average native. These species have as main use its consumption as food (44\%) mainly fruits, flowers and leaves used as vegetables and spices, or for preparing nutritional drinks or infusions (Fig. 3). These species also have other important uses such as firewood and soil and water conservation, all crucial for food processing and without which it would not be produced the vast majority of what is consumed and which constitutes part of the triad suggested by Altieri et al. [69] as part of food sovereignty (energy, technology). In the case of animals, reports describe 684 species (17 domestic and 667 wild), with the principal use is being food (34\%) and other 17 more uses like ornamental, recreation, transportation and for agricultural labor.

Traditional agroecosystems have not only provided to people resources for subsistence, such as food, medicine, and cash incomes, but have played an important role in biodiversity conservation, especially for conserving local species and native crop varieties and germplasm [70]. In México, local agroforestry systems contribute to local food systems and food sovereignty as long as they provide products directed to satisfy the demand of ingredients for local food. These systems are also settings where a great diversity of native varieties of maize, beans and pumpkins, the staple crops are managed, selected and diversified. One first step in the understanding of food sovereignty systems is knowing the local food systems; the inventory of the diversity of actual and

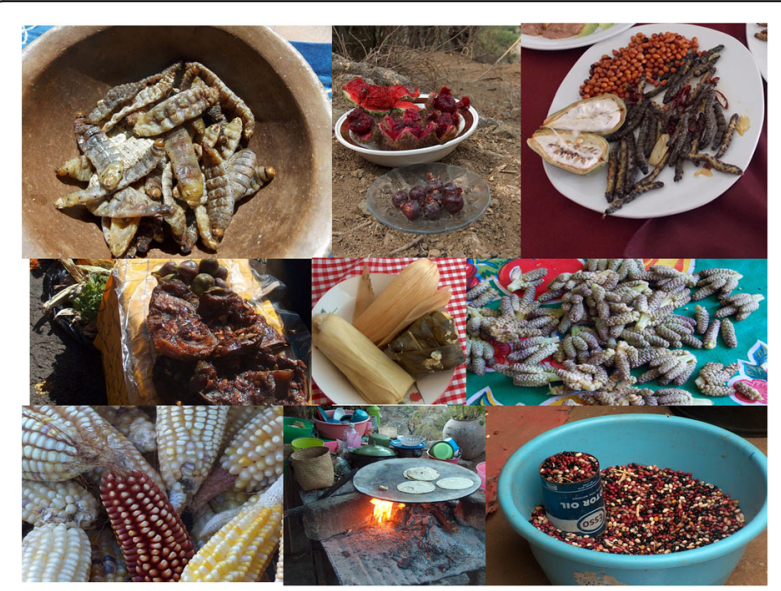

Fig. 3 Food and other resources from Ethnoagroforestry Systems of México 
potential edible resources available, their nutritional contribution, their cultural meanings and the surrounding context, including the ecosystems, landscapes, agroforestry systems, species and varieties used in local food systems [71].

Landscapes in México are composed by of multiple forestry, agriculture and agroforestry systems types, and this guarantee high biodiversity but also diversity in cultural landform management [29]. The main contribution of ethnoagroforestry handling for food sovereignty is the integration of biological and cultural, wild and domestic diversity, at different scales and forms of land management that allow synergy between objectives apparently recognized as opposites: the use and conservation of the biodiversity. The challenge of food sovereignty requires the integration of all bodies of wisdoms, knowledge and practices around the biocultural diversity (human diversity, landscape diversity, agricultural diversity, forest diversity, livestock diversity, wildlife diversity, soil diversity, water diversity, gastronomic diversity, energy diversity, climate diversity). A significant pattern is that as the sample size increases in the studies analyzed the greater wealth of species of plants and animals are incorporated, allowing ensuring conservation of forest and agricultural diversity at landscape scale, as well as at communitarian territory and region, due to the heterogeneity of the households' contributions to the configuration of plots managed through ethnoagroforestry. Homegardens and long fallow lands are mainly used to secure food for home consumption, whereas coffee forest gardens (agroforest) are mainly used to generate cash income [72]. Complex landscapes and management systems may produce major species diversity and more complex food systems and vice versa through spatial and temporal diversity and heterogeneity in diet and landscapes [73]. Diversity of human culture enrich local and global productive and food systems with meanings, beliefs, wisdoms, knowledge and management practices "that is good for eat is god for think before" [74]. In addition, these elements establish the bases for constructing sustainable agroecological management systems [69] for local and global alternatives for food systems [71].

In México, $80 \%$ of forests (55.3 million hectares) are owned by 30,000 traditional communities and ejidos [75], and $81 \%$ of rural economic units are agricultural households (SAGARPA-FAO 2012). Additionally, 14.6 millions of people are recognized by themselves to be indigenous [76], distributed mainly in the center, south and southeastof the country. Agroforestry systems are practiced mainly in "communal" and "ejido" land in the main indigenous areas of México, where decisions are made through local assemblies, which are important institutions for constructing sovereignty processes in relation to access to land, territories, technology and resources. Food sovereignty is the right of nations and people for controlling their own food systems means of production, environments, food cultures and markets [77]. In all these processes, the communal and ejidal assemblies play crucial roles. The connections between food and nutrition security, among indigenous people and the preservation of cultural and biological diversity have been recognized in the "Declaration on the Rights of the Indigenous Peoples" [71]. Many environmental movements of México occur in the distribution area of ethnoagroforestry management zones [78], which indicates that indigenous people are the main promoters of food sovereignty. The organization Tosepan Titataniske, Vicente Guerrero A.C organization, and Grupo de Estudios Ambientales and the Sansekan Tinemi organization and communities are Mexican examples of movements in defense of land, seeds, water, environment and autonomy all elements linked to food sovereignty [79].

In addition to the socio-political contributions [80], the relevance of the concept of food sovereignty compared to the one of food security, promotes ethical reflection on how interactions among people and how people can live together with other humans and other living things to meet the human needs, in the case analyzed food. By placing the emphasis on the ethical implications of current forms of production and consumption there have been drawn questions about the best ways to act without affecting the right the decision processes on diversity, production, access and distribution of food. Similarly, the discussion and decision about the involvement of world views, livelihoods and cultural diversity that until recently were relevant in many humans for food stocks and that are now recognized as "outdated views and wasted lives" [81] and production systems that are part of the agroforestry systems reviewed. The relationship between wasting food and hunger in the world should be re-thinking [82], as well as the effects of production and food systems in nonhuman living, good water, air and soil and the environment in general and their implications for the quality of life and human health [83-85].

\section{Limitations and challenges of traditional agroforestry for food security and sovereignty}

However, the need of integrating biodiversity management, food production systems, food local systems and food security and sovereignty, which are complex issues affecting globally human beings, until recently these issues were addressed separately, emphasizing the importance of research of either social or natural processes instead of integrating both science and social actions for solving food insecurity problems. In the analysis of information of this paper, it is notorious the scarcity of studies on biodiversity productive systems with sovereignty and food security or local food systems concepts $(<10 \%$ of studies analyzed). Nevertheless, nearly $80 \%$ of the 
reports reviewed mention the relevance of agroforestry systems for self-sufficiency of food, medicinal or firewood for cooking. It is relevant that among the wild and weedy components of agroforestry systems, edible plants include numerous species of quelites, the traditional greens that are known to provide important vitamins and fiber to diet, fruits and nuts providing vitamins, proteins and oils, as well as some roots and tubers that contribute with starch and fiber [86]. It is also relevant to mention that numerous species of insects are deliberately protected for ensuring their consumption, which together with hunting animals, are relevant sources of proteins for the traditional diet.

How can we explain the presence of hunger in places where these forms of management are practiced in association with a high biological and cultural diversity? What kind of socioeconomic, politic and cultural processes do not allow access to biological and food diversity? The principal obstacle to use local biodiversity for local food systems is poverty together with discrimination to indigenous food. In many cases studied, people prefer to sale a good food from local biodiversity and with the money paying other needs like, health care and child education. Maize production or other relevant crops for food are commonly insufficient, especially in arid and semiarid zones, where people only produced one third of the annual maize needed for food and fodder and under drought only fodder and seeds for next year [50]. Either staple crops like native maize or wildlife resources of good quality are sold to have economic profit, even if they have to buy other products of lower quality as industrial corn [87]. Another important limitation relates to the abandonment of the consumption of traditional food of high quality and nutritional and cultural value in the past, but that currently are used as fodder or uses other than human consumption, for example the case of ramon (Brosimum alicastrum) in Mayan homegardens [88].

Nowadays, the world faces important dilemmas about the need to preserve biodiversity and ecosystems benefits, at the same time that producing enough food for actual and future generations. The tremendous impact that the modern technology for producing food has caused on natural ecosystems in only few decades indicates that continuing that route is inviable; in other words, it is important recognizing the unviability of maintaining or increasing the rhythms of agricultural production under the technological models predominating throughout the world. Small farms systems cover an important surface of the areas of the world dedicated to produce food, but most of them do not work in the logic of high productivity as agro-industries do. Such small farms are reservoirs of biodiversity, valuable genetic resources and traditional ecological knowledge constructed throughout thousands of years of agricultural experience. All these elements have important signs of local adaptations to attend the local needs through local techniques. But the preliminary systematizations of knowledge and techniques involved in these systems indicate the occurrence of similar principles in common: the importance of maintaining diversity, soils and availability of water. Numerous technological expressions of these principles reveal that the traditional ecological knowledge has functioned with similar motives in different ecological and cultural contexts. Such traditional ecological knowledge and praxis is currently a valuable source of technological options to develop innovations needed to adapt the small farms to the current needs of producing food and other raw matters following sustainable principles. It is a human experience constructed for millennia that deserves to be understood and systematized. Agroecology and Ethnoagroforestry has a high responsibility to construct alternatives to the failed agro-industrial production models, and has in TEK an important source of knowledge and techniques to construct the innovations required for a world that cannot be supported by the disasters caused by the agro-industries.

\section{Conclusions}

Ethnoagroforestry complex are still alive; they maintain staple crops and a high diversity of plant and animal resources, in addition to fungi and microbiota scarcely analyzed. These systems are important reservoirs of biological diversity that is directly consumed as food and complement other needs of the food system as medicines, fuel and other goods and benefits. These systems have enormous advantages in terms of conserving biodiversity, ecosystems integrity and providing resources to people. The main challenges however are their preservation. Several factors associated to the modernity and intensive agricultural systems counteract against these systems. Land tenure is progressively fragmenting and intensification of land use is also increasingly displacing the previous traditional systems maintaining forest cover. However, the systems and people that have driven them are real and their experience is still to be documented. It is not a question of agricultural technique and biodiversity conservation but also a question of human culture and the rationality of a way of living and deciding what to eat and how to eat. These are the elementary bases of food security and sovereignty and basic source of knowledge and techniques for constructing agroecological and ethnoagroforestry innovations for sustainable forms of producing food and raw matters. 


\section{Appendix 1}

Table 2 Reports by agroforestry system type in Mexico with plant species inventory

\begin{tabular}{|c|c|c|c|c|c|c|c|}
\hline Author & State & Municipality & Environment & $\begin{array}{l}\text { Native } \\
\text { people }\end{array}$ & $\begin{array}{l}\text { Number } \\
\text { sampling } \\
\text { units }\end{array}$ & $\begin{array}{l}\text { Number } \\
\text { of } \\
\text { species }\end{array}$ & $\begin{array}{l}\text { Percentage } \\
\text { edible } \\
\text { species (\%) }\end{array}$ \\
\hline \multicolumn{8}{|c|}{ HOMEGARDENS } \\
\hline \multicolumn{8}{|c|}{ Local Reports } \\
\hline $\begin{array}{r}\text { Acosta } \\
\text { et al. (2012) }\end{array}$ & Yucatán & Valladolid & Sub-humid & Maya & $\begin{array}{l}54 \text { plots, } 29 \\
\text { milpas, } 12 \text { on } \\
\text { the road, } 7 \\
\text { on the forest }\end{array}$ & 82 & ND \\
\hline $\begin{array}{l}\text { Aguilar } \\
\text { et al. (2009) }\end{array}$ & Oaxaca & Candelaria Loxicha & Tempered & Mestizo & $\begin{array}{l}31 \\
\text { homegardens }\end{array}$ & 223 & 43 \\
\hline $\begin{array}{l}\text { Aguilar- } \\
\text { Cordero et al. } \\
\text { (2012) }\end{array}$ & Yucatán & Mérida & Sub-humid & Mestizo & ND & 28 & 59 \\
\hline $\begin{array}{l}\quad \text { Aguilar- } \\
\text { Nah et al. } \\
\text { (2012) }\end{array}$ & Campeche & Halachó & Sub-humid & Mestizo & $\begin{array}{l}3 \\
\text { homegardens }\end{array}$ & 112 & ND \\
\hline $\begin{array}{l}\text { Alayon- } \\
\text { Gamboa } \\
\text { (2010) }\end{array}$ & Campeche & Calakmul & Tropical & Mestizo & ND & 31 & 3 \\
\hline $\begin{array}{l}\text { Álvarez- } \\
\text { Lugo (1997) }\end{array}$ & Veracruz & San Andrés Tuxtla & Tropical & Mestizo & $\begin{array}{l}4 \\
\text { homegardens }\end{array}$ & 88 & ND \\
\hline $\begin{array}{l}\quad \text { Ángel- } \\
\text { Pérez y } \\
\text { Alfonso } \\
\text { (2004) }\end{array}$ & Veracruz & Coxquihui & Sub-humid & Totonaco & $\begin{array}{l}40 \\
\text { homegardens }\end{array}$ & 223 & 33 \\
\hline $\begin{array}{c}\text { Ávila } \\
\text { et al. (2012) }\end{array}$ & Yucatán & Mérida & Sub-humid & Mestizo & $\begin{array}{l}21 \\
\text { homegardens }\end{array}$ & 187 & ND \\
\hline $\begin{array}{l}\text { Barrera } \\
\text { (1999) }\end{array}$ & Guerrero & Copalillo & Tempered & $\begin{array}{l}\text { Mestizo/ } \\
\text { nahua }\end{array}$ & ND & 7 & 100 \\
\hline $\begin{array}{l}\quad \text { Bautista- } \\
\text { García et al. } \\
\text { (2014) }\end{array}$ & Tabasco & Cárdenas & Tropical & Mestizo & $\begin{array}{l}29 \\
\text { homegardens }\end{array}$ & 80 & ND \\
\hline $\begin{array}{l}\text { Blanckaert } \\
\text { et al. (2004) }\end{array}$ & Puebla & Coxcatlán & Arid & Mestizo & $\begin{array}{l}30 \\
\text { homegardens }\end{array}$ & 233 & 30 \\
\hline $\begin{array}{l}\quad \text { Burgos- } \\
\text { Lugo et al. } \\
\text { (2012) }\end{array}$ & Yucatán & Maxcanú & Sub-humid & Maya & ND & 120 & 21 \\
\hline $\begin{array}{l}\quad \text { Cano- } \\
\text { Ramírez } \\
\text { (2003) }\end{array}$ & Guerrero & Ayutla de los libre & Sub-humid & Mixteco & $\begin{array}{l}10 \\
\text { homegardens }\end{array}$ & 129 & 39 \\
\hline $\begin{array}{l}\quad \text { Cano- } \\
\text { Ramírez et al. } \\
\text { (2012) }\end{array}$ & Estado de México & Ocuilan & Tempered & Tlahuica & $\begin{array}{l}33 \\
\text { homegardens }\end{array}$ & 287 & 19 \\
\hline $\begin{array}{l}\text { Carrasco- } \\
\text { Hernández } \\
\text { (2011) }\end{array}$ & Hidalgo & Cuautepec de Hinojosa & Tempered & Mestizo & $\begin{array}{l}8 \\
\text { homegardens }\end{array}$ & 120 & 23 \\
\hline $\begin{array}{l}\text { Castillo- } \\
\text { Puc et al. } \\
\text { (2012) }\end{array}$ & Yucatán & Izamal, Peto & Sub-humid & Maya & $\begin{array}{l}30 \\
\text { homegardens }\end{array}$ & 54 & ND \\
\hline Cahuich- & Campeche & Hopelchén & Sub-humid & Maya & $\begin{array}{l}34 \\
\text { homegardens }\end{array}$ & 153 & 33 \\
\hline
\end{tabular}


Table 2 Reports by agroforestry system type in Mexico with plant species inventory (Continued)

\begin{tabular}{|c|c|c|c|c|c|c|c|}
\hline \multicolumn{8}{|l|}{$\begin{array}{l}\text { Campos } \\
(2012)\end{array}$} \\
\hline $\begin{array}{l}\text { Chávez- } \\
\text { Guzmán } \\
\text { et al. (2012) }\end{array}$ & Península de Yucatán & Maxcanú & Sub-humid & Maya & ND & 138 & 33 \\
\hline $\begin{array}{l}\text { Chi } \\
\text { (2012) }\end{array}$ & Campeche & Champotón & Sub-humid & Maya & $\begin{array}{l}12 \\
\text { homegardens }\end{array}$ & 156 & 53 \\
\hline $\begin{array}{l}\text { Contreras- } \\
\text { Cordero et al. } \\
\text { (2012) }\end{array}$ & Yucatán & Maní & Sub-humid & Maya & $\begin{array}{l}50 \\
\text { homegardens }\end{array}$ & 38 & 100 \\
\hline $\begin{array}{l}\text { De Clerk } \\
\text { y Negreros } \\
(2000)\end{array}$ & Quintana roo & ND & ND & Maya & $\begin{array}{l}80 \\
\text { homegardens }\end{array}$ & 78 & 59 \\
\hline $\begin{array}{c}\text { De la } \\
\text { Cruz (2009) }\end{array}$ & Veracruz & Tihuatlán & Sub-humid & Mestizo & ND & 149 & 53 \\
\hline $\begin{array}{l}\quad \text { Escobar- } \\
\text { Hernández } \\
\text { (2013) }\end{array}$ & Chiapas & Unión Juárez & Tempered & Mestizo & $\begin{array}{l}24 \\
\text { homegardens }\end{array}$ & 109 & 35 \\
\hline $\begin{array}{l}\text { Espejel } \\
(1993)\end{array}$ & Puebla & San Juan Epatlán & Tempered & Mestizo & ND & 60 & 43 \\
\hline $\begin{array}{l}\text { Flores } \\
\text { (2012) }\end{array}$ & Yucatán & Mérida & Sub-humid & Maya & $\begin{array}{l}25 \\
\text { homegardens }\end{array}$ & 79 & ND \\
\hline $\begin{array}{c}\text { Flores } \\
\text { et al. (2012) }\end{array}$ & Yucatán & Abala & Sub-humid & Mestizo & $\begin{array}{l}26 \\
\text { homegardens }\end{array}$ & 223 & 46 \\
\hline $\begin{array}{l}\quad \text { Flores, } \\
\text { Balam y } \\
\text { Schober } \\
\text { (2012) }\end{array}$ & Yucatán & Abala & Sub-humid & Maya & ND & 134 & ND \\
\hline $\begin{array}{l}\quad \text { Flores, } \\
\text { Kantun- } \\
\text { Balam, Ortiz } \\
\text { y Lara (2012) }\end{array}$ & Yucatán & Mérida & Sub-humid & Mestizo & ND & 8 & ND \\
\hline $\begin{array}{r}\text { Gispert } \\
\text { et al. (2012) }\end{array}$ & Morelos & Tlaltizapan & Tempered & Mestizo & $\begin{array}{l}10 \\
\text { homegardens }\end{array}$ & 9 & 67 \\
\hline $\begin{array}{l}\quad \text { Gómez- } \\
\text { Álvarez } \\
\text { (2012) }\end{array}$ & Tabasco & Centro & Tropical & Mestizo & ND & 112 & ND \\
\hline $\begin{array}{r}\text { Gómez- } \\
\text { García (2011) }\end{array}$ & Tabasco & Cárdenas & Tropical & Mestizo & ND & 93 & 46 \\
\hline $\begin{array}{l}\text { Gómez- } \\
\text { Gómez } \\
\text { (2010) }\end{array}$ & Tabasco & Cárdenas & Tropical & Mestizo & $\begin{array}{l}126 \\
\text { homegardens }\end{array}$ & 127 & ND \\
\hline $\begin{array}{l}\text { Gomez- } \\
\text { Montes de } \\
\text { Oca (2009) }\end{array}$ & Zacatecas & Fresnillo/Sombrerete & Arid & Mestizo & ND & 140 & 11 \\
\hline $\begin{array}{l}\text { González- } \\
\text { Jiménez et al. }\end{array}$ & México & $\begin{array}{l}\text { Malinalco/Tenancingo/villa } \\
\text { Guerrero }\end{array}$ & Tempered & Mestizo & $\begin{array}{l}60 \\
\text { homegardens }\end{array}$ & 37 & ND \\
\hline $\begin{array}{l}\text { Granados- } \\
\text { Sánchez } \\
\text { (1999) }\end{array}$ & Quintana roo & Carrillo Puerto & Sub-humid & Maya & ND & 127 & 48 \\
\hline $\begin{array}{l}\text { Guerrero-Leal } \\
\text { (2014) }\end{array}$ & Tlaxcala & Españita & Tempered & Mestizo & $\begin{array}{l}45 \\
\text { homegardens }\end{array}$ & 28 & 86 \\
\hline & Yucatán & Mérida & Sub-humid & Mestizo & ND & 17 & ND \\
\hline
\end{tabular}


Table 2 Reports by agroforestry system type in Mexico with plant species inventory (Continued)

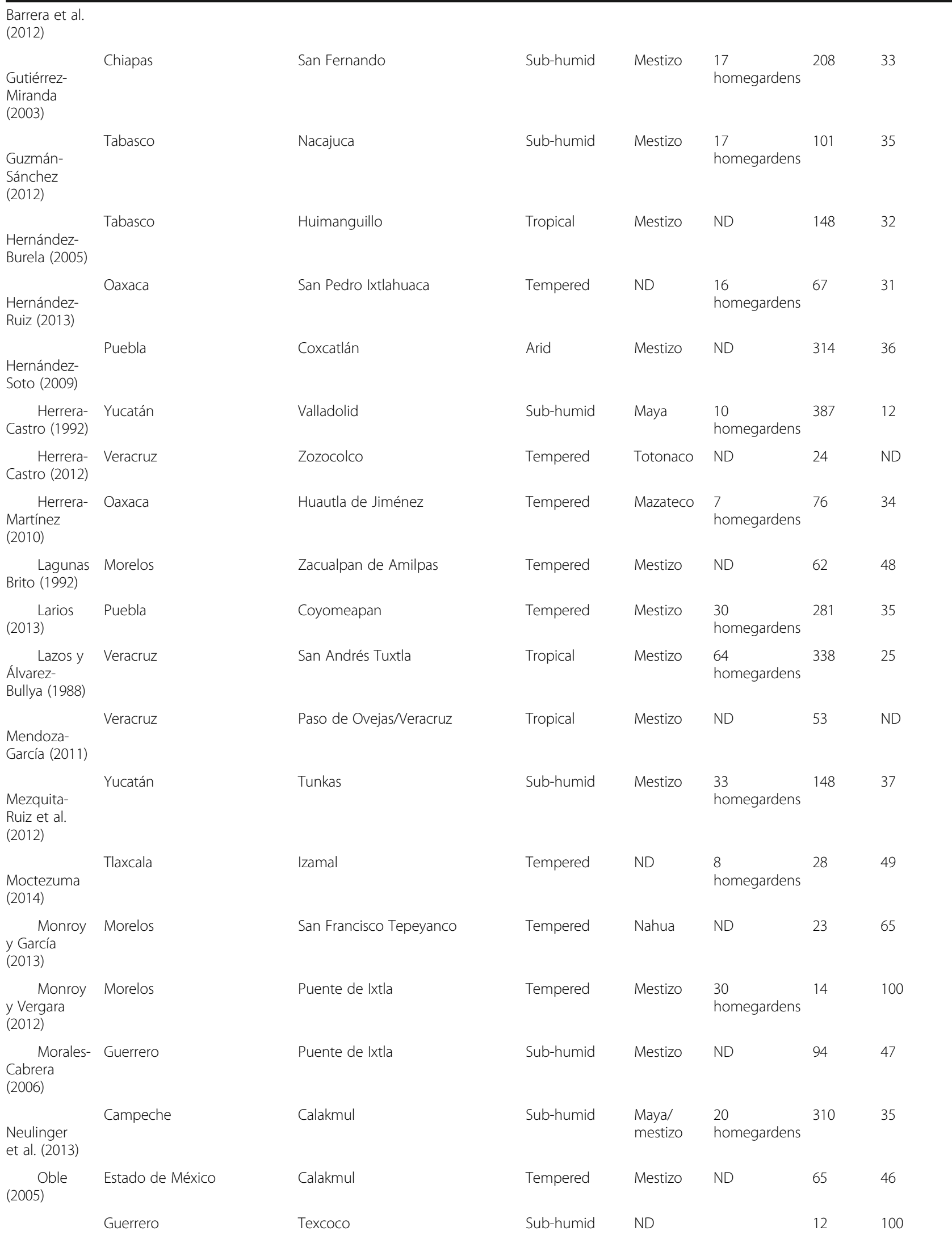


Table 2 Reports by agroforestry system type in Mexico with plant species inventory (Continued)

\begin{tabular}{|c|c|c|c|c|c|c|c|}
\hline $\begin{array}{r}\text { Orizaba } \\
\text { Tovar (2008) }\end{array}$ & & & & & $\begin{array}{l}26 \\
\text { homegardens }\end{array}$ & & \\
\hline $\begin{array}{l}\text { Ortiz- } \\
\text { León (2012) }\end{array}$ & ND & San Miguel Totolapan & Tempered & ND & 16 fincas & & ND \\
\hline $\begin{array}{l}\quad \text { Osorio- } \\
\text { Mendoza } \\
\text { (2007) }\end{array}$ & Guerrero & ND & Sub-humid & Mestizo & ND & 99 & 45 \\
\hline $\begin{array}{l}\text { Osornio } \\
\text { et al. (1999) }\end{array}$ & Península de Yucatán & Ayutla de los Libres & Tropical & ND & ND & 24 & ND \\
\hline $\begin{array}{l}\quad \text { Pérez- } \\
\text { Ramírez } \\
\text { (2012) }\end{array}$ & Tabasco & Tlacuilotepec & Tropical & ND & $\begin{array}{l}107 \\
\text { homegardens }\end{array}$ & 145 & ND \\
\hline $\begin{array}{l}\text { Perezgrovas } \\
(2011)\end{array}$ & Chiapas & Venustiano Carranza & Tempered & Tzeltal & ND & 15 & 33 \\
\hline $\begin{array}{l}\quad \text { Pérez- } \\
\text { Ramírez et al. } \\
\text { (2012) }\end{array}$ & Tabasco & ND & Tropical & ND & $\begin{array}{l}58 \\
\text { homegardens }\end{array}$ & 180 & ND \\
\hline $\begin{array}{l}\text { Poot- } \\
\text { Pool et al. } \\
\text { (2012) }\end{array}$ & Campeche & Hecelchakán & Tropical & Mestizo & $\begin{array}{l}24 \\
\text { homegardens }\end{array}$ & 236 & 24 \\
\hline $\begin{array}{l}\text { Puente } \\
\text { Pardo et al. } \\
\text { (2010) }\end{array}$ & Tabasco & Hecelchakán & Tropical & Mestizo & $\begin{array}{l}32 \\
\text { homegardens }\end{array}$ & 56 & ND \\
\hline $\begin{array}{l}\text { Ramos- } \\
\text { Zapata et al. } \\
\text { (2012) }\end{array}$ & Yucatán & Huimanguillo & Sub-humid & Mestizo & $\begin{array}{l}5 \\
\text { homegardens }\end{array}$ & 8 & ND \\
\hline $\begin{array}{l}\quad \text { Rebollar } \\
\text { Domínguez } \\
\text { et al. (2008) }\end{array}$ & Quintana Roo & Mérida & Sub-humid & Maya & $\begin{array}{l}20 \\
\text { homegardens }\end{array}$ & 43 & 59 \\
\hline $\begin{array}{l}\quad \text { Rico } \\
\text { Gray et al. } \\
\text { (1991) }\end{array}$ & Yucatán & Yaxcabá/Tixpéhual & Sub-humid & Mestizo & $\begin{array}{l}42 \\
\text { homegardens }\end{array}$ & 301 & 30 \\
\hline $\begin{array}{l}\quad \text { Rivera } \\
\text { Lozoya } \\
\text { (2013) }\end{array}$ & San Luis Potosí & Mérida & Tempered & Teenek & $\begin{array}{l}18 \\
\text { homegardens }\end{array}$ & 208 & 44 \\
\hline $\begin{aligned} & \text { Roces } \\
& \text { et al. (1989) }\end{aligned}$ & Veracruz & Aquismón & Tropical & Mestizo & $\begin{array}{l}8 \\
\text { homegardens }\end{array}$ & 338 & ND \\
\hline $\begin{array}{l}\quad \text { Ruenes } \\
\text { Morales } \\
\text { (1993) }\end{array}$ & Nayarit & San Andres Tuxtla & Tempered & Mestizo & $\begin{array}{l}10 \\
\text { homegardens }\end{array}$ & 201 & 27 \\
\hline $\begin{array}{l}\text { Salgado } \\
\text { Mora (2010) }\end{array}$ & Chiapas & Huehuetan/Tuxtla Chico & Tempered & Mestizo & $\begin{array}{l}24 \\
\text { homegardens }\end{array}$ & 123 & 67 \\
\hline $\begin{array}{l}\quad \text { Sánchez } \\
\text { Velázquez } \\
\text { (2008) }\end{array}$ & Puebla & $\begin{array}{l}\text { Santo Domingo Huehuetlán El } \\
\text { Grande }\end{array}$ & Arid & Mestizo & $\begin{array}{l}10 \\
\text { homegardens }\end{array}$ & 199 & 26 \\
\hline $\begin{array}{l}\text { Santoyo } \\
(2004)\end{array}$ & Puebla & Tehuacán & Arid & Mestizo & ND & 90 & 35 \\
\hline $\begin{array}{l}\quad \text { Solís } \\
\text { Becerra } \\
\text { (2013) }\end{array}$ & Chiapas & Teopisca & Tempered & Mestizo & $\begin{array}{l}3 \\
\text { homegardens }\end{array}$ & 13 & 100 \\
\hline $\begin{array}{c}\text { Tamayo } \\
\text { Ortega (1985) }\end{array}$ & Tabasco & Comalcalco & Tropical & Chontal & $\begin{array}{l}9 \\
\text { homegardens }\end{array}$ & 242 & 37 \\
\hline $\begin{array}{r}\text { Torres } \\
\text { Díaz (2011) }\end{array}$ & Chiapas & La trinitaria & Tempered & Mestizo & $\begin{array}{l}30 \\
\text { homegardens }\end{array}$ & 133 & 58 \\
\hline $\begin{array}{c}\text { Torres } \\
\text { Rosas (2010) }\end{array}$ & Tabasco & Cárdenas & Tropical & Mestizo & $\begin{array}{l}6 \\
\text { homegardens }\end{array}$ & 130 & 47 \\
\hline
\end{tabular}


Table 2 Reports by agroforestry system type in Mexico with plant species inventory (Continued)

\begin{tabular}{|c|c|c|c|c|c|c|c|}
\hline $\begin{array}{r}\text { Vásquez } \\
\text { García (2007) }\end{array}$ & Veracruz & Mecayapan, Soteapan & Tempered & $\begin{array}{l}\text { Nahua/ } \\
\text { popoluca }\end{array}$ & ND & 28 & 100 \\
\hline $\begin{array}{l}\quad \text { Vázquez } \\
\text { Medina } \\
\text { (2010) }\end{array}$ & Puebla & Coyomeapan & Tempered & Nahua & ND & 51 & ND \\
\hline $\begin{array}{l}\text { Vibrans } \\
\text { et al. (2001) }\end{array}$ & Estado de México & Texcoco & Tempered & Mestizo & $\begin{array}{l}20 \\
\text { homegardens }\end{array}$ & 303 & ND \\
\hline $\begin{array}{l}\text { Vilamajó } \\
\text { et al. (2011) }\end{array}$ & Chiapas & Rayón & Tempered & Zoque & $\begin{array}{l}10 \\
\text { homegardens }\end{array}$ & 63 & 36 \\
\hline $\begin{array}{l}\text { Zaragoza } \\
\text { et al. (2011) }\end{array}$ & Chiapas & Chamula & Tempered & & ND & 31 & 81 \\
\hline \multicolumn{8}{|c|}{ Regional reports } \\
\hline $\begin{array}{l}\quad \text { Cámara- } \\
\text { Córdova } \\
\text { (2012) }\end{array}$ & Tabasco & Todo el estado & Tropical & ND & ND & 141 & ND \\
\hline $\begin{array}{l}\quad \text { Cetz- } \\
\text { Zapata et al. } \\
(2012)\end{array}$ & Yucatán & ND & Sub-humid & $\begin{array}{l}\text { Mestizo/ } \\
\text { maya }\end{array}$ & $\begin{array}{l}97 \\
\text { homegardens }\end{array}$ & 86 & ND \\
\hline $\begin{array}{l}\text { Chablé- } \\
\text { Pascal et al. } \\
\text { (2015) }\end{array}$ & Tabasco & $\begin{array}{l}\text { Huimanguillo/Cárdenas/ } \\
\text { Comalcalco }\end{array}$ & Tropical & Mestizo & $\begin{array}{l}27 \\
\text { homegardens }\end{array}$ & 330 & 42 \\
\hline $\begin{array}{l}\quad \text { Flores, } \\
\text { Dillword y } \\
\text { Kantun- } \\
\text { Balam (2012) }\end{array}$ & Península de Yucatán & $\begin{array}{l}\text { Cancún, Isla Contoy, Isla Mujeres, } \\
\text { Tulum, Playa del Carmen, Isla } \\
\text { Holbox, Isla Blanca, Cayo Sucio, } \\
\text { Banco Chinchorro }\end{array}$ & Tropical & Mestizo & ND & 96 & ND \\
\hline $\begin{array}{l}\quad \text { Flores, } \\
\text { Garrido, Ortiz } \\
\text { y Santos } \\
\text { (2012) }\end{array}$ & Península de Yucatán & ND & Sub-humid & Mestizo & $\begin{array}{l}15 \\
\text { homegardens }\end{array}$ & 265 & ND \\
\hline $\begin{array}{c}\text { Flores- } \\
\text { Guido (2012) }\end{array}$ & Península de Yucatán & $\begin{array}{l}\text { Área Maya de la Península de } \\
\text { Yucatán }\end{array}$ & Sub-humid & & $\begin{array}{l}300 \\
\text { homegardens }\end{array}$ & 524 & 15 \\
\hline $\begin{array}{l}\text { García } \\
\text { de Miguel } \\
\text { (1998) }\end{array}$ & Península de Yucatán & $\begin{array}{l}\text { Abala, Temax, Ucu, Calkini } \\
\text { (Nunkini), Campeche (Hampolol), } \\
\text { Tenabo, Maní, Tzucacab, Jóse } \\
\text { Maria Morelos (Dziuche), Lázaro } \\
\text { Cárdenas (Kantunilkin), Sucila, } \\
\text { Tizimin (Tixcancal), Felipe Carrillo } \\
\text { Puerto (Tihosuco), Chemax, } \\
\text { Chichimila }\end{array}$ & Sub-humid & Maya & $\begin{array}{l}300 \\
\text { homegardens }\end{array}$ & 156 & 59 \\
\hline $\begin{array}{c}\text { García- } \\
\text { Ramos (2010) }\end{array}$ & Oaxaca & $\begin{array}{l}\text { Constancia del Rosario/Putla Villa } \\
\text { de Guerrero/San Andrés Cabecera } \\
\text { Nueva/Santa María Zacatepec }\end{array}$ & Tempered & $\begin{array}{l}\text { Triqui/ } \\
\text { mixteco/ } \\
\text { mestizo }\end{array}$ & $\begin{array}{l}13 \\
\text { homegardens }\end{array}$ & 285 & 34 \\
\hline $\begin{array}{l}\text { Magaña } \\
\text { (2012) }\end{array}$ & Tabasco & 8 municipios de Tabasco & Tropical & ND & ND & 495 & ND \\
\hline $\begin{array}{l}\quad \text { Mariaca- } \\
\text { Méndez } \\
\text { (2012) }\end{array}$ & Chiapas & Sureste Mexicano & $\begin{array}{l}\text { Sub-humid/ } \\
\text { Tropical }\end{array}$ & ND & ND & 418 & ND \\
\hline $\begin{array}{l}\quad \text { Pagaza- } \\
\text { Calderón } \\
\text { (2008) }\end{array}$ & Puebla & ND & Tempered & $\begin{array}{l}\text { Totonaco/ } \\
\text { otomie/ } \\
\text { nahua/ } \\
\text { mestizo }\end{array}$ & $\begin{array}{l}53 \\
\text { homegardens }\end{array}$ & 404 & ND \\
\hline $\begin{array}{l}\quad \text { Ruenes } \\
\text { Morales y } \\
\text { Montañez } \\
\text { Escalante } \\
\text { (2015) }\end{array}$ & Campeche & $\begin{array}{l}\text { Hopelchén, Tenabo, Campeche, } \\
\text { Champotón, Escárcega, Calakmul, }\end{array}$ & Tropical & ND & ND & 174 & ND \\
\hline $\begin{array}{l}\text { Ruenes } \\
\text { Morales y }\end{array}$ & Quintana Roo & $\begin{array}{l}\text { Othón P.B., J.M. Morelos, F.C. } \\
\text { Puerto, Solidaridad }\end{array}$ & Tropical & ND & ND & 310 & ND \\
\hline
\end{tabular}


Table 2 Reports by agroforestry system type in Mexico with plant species inventory (Continued)

Montañez

Escalante

(2015)

\begin{tabular}{|c|c|}
\hline $\begin{array}{l}\quad \text { Ruenes } \\
\text { Morales y } \\
\text { Montañez } \\
\text { Escalante } \\
\text { (2015) }\end{array}$ & Yucatán \\
\hline \multicolumn{2}{|c|}{ WETLAND AGRO } \\
\hline Local Repo & \\
\hline $\begin{array}{l}\text { Jiménez- } \\
\text { Osornio y } \\
\text { Gómez- } \\
\text { Pompa } \\
\text { (1990) }\end{array}$ & Distrito Federal \\
\hline $\begin{array}{l}\text { López- } \\
\text { Ríos (1984) }\end{array}$ & Distrito Federal \\
\hline $\begin{array}{l}\text { Nava } \\
(2007)\end{array}$ & Tlaxcala \\
\hline $\begin{array}{l}\quad \text { Ochoa y } \\
\text { Gonzáles } \\
\text { (2009) }\end{array}$ & Campeche \\
\hline
\end{tabular}

Sánchez

et al. (2004)
Venegas Distrito Federal (1978)

Tekax, Hocabá, Maní, Celestún, Telchac Puerto, Uman, Mérida,

Abalá

Tropical

ND

ND

223

ND

Tláhuac

Tempered

Mestizo

ND

146

ND

Xochimilco

Ixtacuixtla de Mariano de Matamoros

Xicalanco

Nacajuca

Tláhuac

LONG FALLOW AGROFORESTRY

Local Reports

$$
\text { Berlín Chiapas }
$$

et al. (2001)

\author{
Chiapas
}

Blanco- Veracruz

Rosas (2006)

$$
\text { Chiapas }
$$

Diemont

et al. (2006)

Hellier

et al. (1999)

Chiapas

Chihuahua

LaRochelle

(2003)

Ochoa- Chiapas

Gaona et al.

(2007)

(2005)

Otero Guerrero

Regional Reports

Aguilar Guerrero

et al.

AGROFOREST

Local Reports

$$
\text { Rosales Jalisco y Nayarit }
$$
Adame et al. (2014)
Región de los Altos de Chiapas

Sub-humid

Tzeltal/

Tzotzil/

Tojolabal

Soteapan

Ocosingo

Comitán

Guachochi

Palenque/Ocosingo

Acapulco de Juárez

Zitlala/Chilapa/Ahuacuotzingo/

Mártir de Cuilapan

Tropical

Tropical

Sub-humid

Tempered

Sub-humid

Sub-humid

Mestizo

ND

Sub-humid

Nahua

ND

39 plots

119

ND

Ixcuintla.
ND

ND

Sub-humid

69

ND 
Table 2 Reports by agroforestry system type in Mexico with plant species inventory (Continued)

\begin{tabular}{|c|c|c|c|c|c|c|c|}
\hline $\begin{array}{l}\text { Baeza } \\
(2003)\end{array}$ & Oaxaca & $\begin{array}{l}\text { Santiago Nuyoo/Santa María } \\
\text { Yucuite }\end{array}$ & Tempered & Ñuu Savi & 12 plots & 87 & 51 \\
\hline $\begin{array}{l}\quad \text { García } \\
\text { Burgos et al. } \\
\text { (2014) }\end{array}$ & Veracruz & Totutla & Sub-humid & ND & ND & 13 & ND \\
\hline $\begin{array}{l}\text { Gómez- } \\
\text { Pompa et al. } \\
\text { (2012) }\end{array}$ & Yucatán & Yaxcabá, Dzoncauich & Tropical & Maya & $\begin{array}{l}5 \text { peet } \\
\text { kotoob }\end{array}$ & 48 & ND \\
\hline $\begin{array}{l}\text { Ibarra } \\
\text { et al. (2001) }\end{array}$ & Tabasco & Comacalco y Paraíso & Tropical & ND & ND & 84 & ND \\
\hline $\begin{array}{l}\text { Lucio- } \\
\text { Palacio et al. } \\
\text { (2015) }\end{array}$ & Chiapas & Tapachula & Tropical & ND & ND & 76 & ND \\
\hline $\begin{array}{l}\quad \text { Martínez } \\
\text { López et al. } \\
\text { (2011) }\end{array}$ & Tabasco & Cunduacán & Tropical & ND & ND & 25 & ND \\
\hline $\begin{array}{r}\text { Muñoz } \\
\text { et al. (2006) }\end{array}$ & Tabasco & Comalcalco & Tropical & ND & 1 plot & 16 & ND \\
\hline $\begin{array}{l}\text { Peeters } \\
\text { et al. (2003) }\end{array}$ & Chiapas & $\begin{array}{l}\text { Jitolol de Zaragoza Plan de } \\
\text { Paredón }\end{array}$ & Tropical & Zoque & ND & 46 & 56 \\
\hline $\begin{array}{r}\text { Ramírez } \\
\text { López (2012) }\end{array}$ & Chiapas & Chenalhó & Tropical & Tsotsil & ND & 138 & ND \\
\hline $\begin{array}{l}\quad \text { Ramírez- } \\
\text { Meneses } \\
\text { et al. (2013) }\end{array}$ & Tabasco & Cárdenas & Tropical & ND & ND & 44 & ND \\
\hline $\begin{array}{l}\quad \text { Roa- } \\
\text { Romero } \\
\text { (2009) }\end{array}$ & Chiapas & $\begin{array}{l}\text { Huehuetaán/Tapachula/Tuxtla } \\
\text { Chico }\end{array}$ & Sub-humid & ND & 28 plots & 46 & 48 \\
\hline $\begin{array}{l}\text { Salgado- } \\
\text { Mora (2007) }\end{array}$ & Chiapas & $\begin{array}{l}\text { Tuzántan/Huehuetán/Tapachula/ } \\
\text { Tuxtla Chico }\end{array}$ & Sub-humid & ND & 80 plots & 47 & 48 \\
\hline $\begin{array}{l}\text { Sánchez- } \\
\text { Gutiérrez } \\
\text { (2012) }\end{array}$ & Tabasco & Cárdenas & Sub-humid & ND & 20 plots & 67 & ND \\
\hline $\begin{array}{l}\text { Saucedo } \\
\text { García et al. } \\
\text { (2014) }\end{array}$ & Veracruz & Coatepec/Huatusco & Sub-humid & ND & ND & 24 & ND \\
\hline $\begin{array}{c}\text { Soto } \\
\text { Pinto }(2000)\end{array}$ & Chiapas & Chilón & Tropical & Tzeltal & ND & 61 & 41 \\
\hline $\begin{array}{l}\quad \text { Tlapaya } \\
\text { y Gallina } \\
\text { (2010) }\end{array}$ & Veracruz & Teocelo, Coatepec y Huastuco & Sub-humid & ND & ND & 16 & 75 \\
\hline $\begin{array}{l}\quad \text { Ventura- } \\
\text { Aquino } \\
\text { (2008) }\end{array}$ & Oaxaca & San Agustin Loxica & Tempered & Zapoteco & ND & 49 & ND \\
\hline $\begin{array}{l}\text { Villavicencio } \\
\text { y Valdez } \\
\text { (2003) }\end{array}$ & Veracruz & Amatlán de los reyes & Tropical & Mestizo & 34 plots & 81 & ND \\
\hline Regional Rer & ports & & & & & & \\
\hline $\begin{array}{l}\text { Espejo } \\
\text { Serna et al. } \\
\text { (2005) }\end{array}$ & $\begin{array}{l}\text { Sinaloa, Durango, Nayarit, } \\
\text { Jalisco, Guerrero, Oaxaca, } \\
\text { Chiapas, Tabasco, Veracruz, } \\
\text { Puebla, Hidalgo, San Luis } \\
\text { Potosi, Querétaro, }\end{array}$ & ND & $\begin{array}{l}\text { Arid, } \\
\text { sub.humid, } \\
\text { tempered and } \\
\text { tropical }\end{array}$ & ND & ND & 213 & ND \\
\hline $\begin{array}{l}\text { Martínez } \\
\text { et al. (2007) }\end{array}$ & Puebla & Sierra Norte de Puebla & Tempered & $\begin{array}{l}\text { Totonaco/ } \\
\text { Tepehua/ }\end{array}$ & ND & 319 & 48 \\
\hline
\end{tabular}


Table 2 Reports by agroforestry system type in Mexico with plant species inventory (Continued)

\begin{tabular}{|c|c|c|c|c|c|c|c|}
\hline & & & & $\begin{array}{l}\text { Nahua/ } \\
\text { Otomie/ } \\
\text { Mestizo }\end{array}$ & & & \\
\hline \multicolumn{8}{|c|}{ TERRACES AND SEMI-TERRACES AGROFORESTRY } \\
\hline \multicolumn{8}{|c|}{ Local Reports } \\
\hline $\begin{array}{c}\text { Altieri y } \\
\text { Trujillo (1987) }\end{array}$ & Tlaxcala & Tlaxcala & $\begin{array}{l}\text { Tempered/ } \\
\text { Sub-humid }\end{array}$ & Mestizo & ND & 22 & 14 \\
\hline $\begin{array}{l}\text { Miranda } \\
\text { et al. (2003) }\end{array}$ & Tlaxcala & Españita & $\begin{array}{l}\text { Tempered/ } \\
\text { Sub-humid }\end{array}$ & Mestizo & ND & 153 & ND \\
\hline $\begin{array}{l}\text { Patrick } \\
\text { (1977) }\end{array}$ & Tlaxcala & Miguel Hidalgo y Costilla & $\begin{array}{l}\text { Tempered/ } \\
\text { Sub-humid }\end{array}$ & Mestizo & ND & 3 & ND \\
\hline $\begin{array}{l}\quad \text { Pérez } \\
\text { Sánchez } \\
\text { (2012) }\end{array}$ & Tlaxcala & Ixtacuixtla & $\begin{array}{l}\text { Tempered/ } \\
\text { Sub-humid }\end{array}$ & Mestizo & ND & 25 & 24 \\
\hline \multicolumn{8}{|c|}{ ARID AND SEMIARID AGROFORESTRY } \\
\hline \multicolumn{8}{|c|}{ Local Reports } \\
\hline $\begin{array}{l}\text { Blanckaert } \\
\text { et al. (2007) }\end{array}$ & Oaxaca & Teotitlán de Flores Magón & Semi-arid & $\begin{array}{l}\text { Mestizos y } \\
\text { pocos } \\
\text { Mazatecos }\end{array}$ & ND & 43 & 7 \\
\hline $\begin{array}{l}\text { Campos- } \\
\text { Salas (2015) }\end{array}$ & Puebla & Atexcal & $\begin{array}{l}\text { Semi-arid/ } \\
\text { Tempered }\end{array}$ & Mestizos & ND & 69 & ND \\
\hline $\begin{array}{l}\text { Hoogesteger } \\
\text { et al. (2016) }\end{array}$ & Guanajuato & Xichú & $\begin{array}{l}\text { Semi-arid/ } \\
\text { Tempered }\end{array}$ & Mestizos & 9 plots & 72 & 24 \\
\hline $\begin{array}{l}\text { Moreno- } \\
\text { Calles et al. } \\
\text { (2012) }\end{array}$ & Oaxaca & Caltepec & Semi-arid & Mestizos & 9 plots & 122 & 16 \\
\hline $\begin{array}{l}\text { Nabham } \\
\text { et al. } 1982\end{array}$ & Sonora & Puerto Peñasco & Arid & Mestizos & $\begin{array}{l}38 \\
\text { homegardens }\end{array}$ & 81 & 53 \\
\hline $\begin{array}{l}\text { Stienen } \\
\text { (1990) }\end{array}$ & $\begin{array}{l}\text { Nuevo León, Tamaulipas y } \\
\text { Coahuila }\end{array}$ & Linares & Semi-arid & Mestizos & ND & 28 & 75 \\
\hline \multicolumn{8}{|c|}{ Regional Reports } \\
\hline $\begin{array}{l}\text { Moreno } \\
\text { Calles et al. } \\
\text { (2010) }\end{array}$ & Puebla/Oaxcaca & $\begin{array}{l}\text { Caltepec/Zapotitlán Salinas/Santa } \\
\text { María Tecomavaca }\end{array}$ & Semi-arid & Mestizos & 6 plots & 134 & 18 \\
\hline $\begin{array}{l}\text { Nabham } \\
\text { et al. (2010) }\end{array}$ & Baja California & Varios & $\begin{array}{l}\text { Mediterranean/ } \\
\text { Arid }\end{array}$ & Mestizos & ND & 71 & ND \\
\hline $\begin{array}{c}\text { Vallejo } \\
\text { Ramos (2015) }\end{array}$ & Puebla & $\begin{array}{l}\text { Coyomeapan, San José } \\
\text { Miahuatlán, San Pedro Ixcatlán, } \\
\text { Concepción Pápalo, San Juan } \\
\text { Bautista Cuicatlán, Zapotitlán }\end{array}$ & $\begin{array}{l}\text { Semi-arid/ } \\
\text { Tempered }\end{array}$ & $\begin{array}{l}\text { Náhuatl, } \\
\text { Ixcatecos, } \\
\text { Cuicatecos }\end{array}$ & 15 plots & 66 & ND \\
\hline \multicolumn{8}{|c|}{ AGROSILVOPASTORIL SYSTEMS } \\
\hline $\begin{array}{l}\quad \text { Bautista } \\
\text { (2009); } \\
\text { Bautista- } \\
\text { Tolentino } \\
\text { et al. (2011) }\end{array}$ & Veracruz & Paso de ovejas & $\begin{array}{l}\text { Warm/Sub- } \\
\text { humid }\end{array}$ & ND & 26 plots & 14 & ND \\
\hline $\begin{array}{l}\text { Jiménez- } \\
\text { Ferrer } \\
\text { et al.(2007) }\end{array}$ & Chiapas & Trinitaria & Tempered & ND & ND & 13 & ND \\
\hline $\begin{array}{l}\quad \text { Ramírez- } \\
\text { Marcial et al. } \\
\text { (2012) }\end{array}$ & Chiapas & Ocozocouautla de Espinosa & $\begin{array}{l}\text { Warm/Sub- } \\
\text { humid }\end{array}$ & Zoque & 5 Farms & $\begin{array}{l}59 \text { in } \\
\text { ASPS } \\
\text { and SPS }\end{array}$ & ND \\
\hline $\begin{array}{c}\text { Vargas- } \\
\text { López (2003) }\end{array}$ & Puebla & $\begin{array}{l}\text { Cuautinchan/Tecali/Tzicatlacoyan/ } \\
\text { Puebla }\end{array}$ & $\begin{array}{l}\text { Semi-arid/ } \\
\text { Tempered }\end{array}$ & ND & 7 Farms & 5 & ND \\
\hline
\end{tabular}




\section{Appendix 2}

Table 3 Reports by agroforestry system type in Mexico with animal species inventory

\begin{tabular}{lll}
\hline Autor & State & $\begin{array}{l}\text { Species by } \\
\text { report }\end{array}$ \\
\hline $\begin{array}{ll}\text { HOMEGARDENS } \\
\text { Álvarez Lugo (1997) }\end{array}$ & Veracruz & 5 \\
Cahuich Campos (2012) & Campeche & 14 \\
Chi (2012) & Campeche & 8 \\
Charblé-Santos et al. (2012 & Yucatán & 12 \\
Cruz Bojórquez (2012) & Yucatán & 1 \\
Domínguez Santos et al. (2012) & Yucatán & 57 \\
Granados Sánchez et al. (1999) & Quintana Roo & 9 \\
Hernández Soto (2009) & Puebla & 8 \\
Mariaca Méndez 2012 & Yucatán & 47 \\
Montañez Escalante et al. 2012 & Yucatán & 37 \\
Neulinger et al. 2012 & Campeche & 12 \\
Zaragoza et al. 2011 & Chiapas & 7
\end{tabular}

WETLAND AGROFORESTRY SYSTEMS

Cahero 1997
Ochoa y González -Jácome
(2009)

$\begin{array}{ll}\text { Tabasco } & 9 \\ \text { Campeche } & 35\end{array}$

Osorio et al. (2004)
Mariaca (1999)
Brown (1999)
Chávez (1999)
Pineda et al. (1999)
Pérez-Sánchez (2008)
ONG FALLOW AGROFORESTRY

Blanco Rosas (2006)

Hellier et al. (1999)

Flores Cruz (2011)

AGROFOREST

Aragón y López-Paniagua
(2015)
De Haro (2006)
Gallina et al. (1996)
Ibarra et al. (2001)
Greenberg et al. (2000)
González-Ortega et al. (2011)
Cruz-Parra (2012)
Marcíp-Rios y Muñoz-Alonso
(2008)

Mendoza-Sáenz (2012)
Brito-Ríos (2015)
Mérida-Rivas (2010)

$\begin{array}{ll}\text { Tabasco } & 28 \\ \text { Tabasco } & 6 \\ \text { Tabasco } & 8 \\ \text { Tabasco } & 20 \\ \text { Tabasco } & 7 \\ \text { Tabasco } & 14\end{array}$

Veracruz 18

Chiapas 28

Oaxaca 9

Puebla 99

Veracruz $\quad 107$

Veracruz 24

Tabasco $\quad 84$

Tabasco 81

Chiapas 13

Chiapas 21

Chiapas $\quad 16$

Chiapas $\quad 25$

Jalisco $\quad 39$

Chiapas 27
Table 3 Reports by agroforestry system type in Mexico with animal species inventory (Continued)

\begin{tabular}{lll}
\hline Cruz-Lara et al. (2004) & Chiapas & 43 \\
Escamilla (2008) & Veracruz & 3 \\
De la Mora et al. (2008) & Chiapas & 2 \\
Philpott (2005) & Chiapas & 6 \\
Tlapaya y Gallina (2010) & Veracruz & 18 \\
Murieta-Galindo et al. (2013) & Veracruz & 19 \\
ARID AND SEMIARID AGROFORESTRY & \\
Zuria y Gates (2013) & Guanajuato (el & 61 \\
Nabhan et al. (1982) & Bajío) & \\
Ortíz et al. (2010) & Sonora & 43 \\
\hline
\end{tabular}

\section{Abbreviations}

AFS: Agroforestry systems; CONEVAL: Consejo Nacional de Evaluación de la Política de Desarrollo Social; FAO: Food and Agriculture Organization of the United Nations; INEGI: Instituto Nacional de Estadística y Geografía

\section{Acknowledgements}

Not applicable.

\section{Funding}

The authors acknowledge the support in the design of the study and collection, analysis, and interpretation of data and writing the manuscript of the project UNAM DGAPA 203115 PAPIIT IA "Manejo etnoagroforestal de la biodiversidad en México: Uso y conservación".

\section{Availability of data and materials}

Data are attachment to the manuscript.

\section{Authors' contributions}

AIMC is the first author and main coordinator of the research project study. ADRM, YAR, RAFO development throughout the course of this work, from planning, fieldwork, interviews, data analysis and writing of this paper. AC, FAR, MVA, DSF, SRL are experts in ethnobiology themes and assisted paper writing. All authors read and approved the final manuscript author contributions.

\section{Author's information}

AIMC and FAR are researchers at the Escuela Nacional de Estudios Superiores, Morelia. AC is full time researcher at Instituto de Investigaciones en Ecosistemas y Sustentabilidad, UNAM. ADRR, YARR, RAFO are stunts at te Escuela Nacional de Estudios Superiores Unidad Morelia. SRL is a PhD suden at Instituto de Investigaciones en Ecosistemas y Sustentabilidad. MVR is posdoctoral fellowship in Centro de Investigaciones en Geografía Ambiental. DSF is a researcher at Universidad del Estado de México.

\section{Competing interests}

The authors declare that they have no competing interests.

\section{Consent for publication}

Don't applicable.

Ethics approval and consent to participate

Don't applicable.

\section{Author details}

'Escuela Nacional de Estudios Superiores Unidad Morelia (ENES), Universidad Nacional Autónoma de México. UNAM, Campus Morelia, Antigua Carretera a Pátzcuaro No. 8701, Col. Ex-Hacienda de San José de la Huerta, Morelia 58190, Michoacán, México. ${ }^{2}$ Instituto de Investigaciones en Ecosistemas y Sustentabilidad (IIES), Universidad Nacional Autónoma de México. UNAM, Campus Morelia, Antigua Carretera a Pátzcuaro No. 8701, Col. Ex-Hacienda 
de San José de la Huerta, Morelia 58190, Michoacán, México. ${ }^{3}$ Centro de Investigaciones en Geografía Ambiental, Universidad Nacional Autónoma de México (CIGA). UNAM, Campus Morelia, Antigua Carretera a Pátzcuaro No. 8701, Col. Ex-Hacienda de San José de la Huerta, Morelia 58190, Michoacán México. ${ }^{4}$ Centro Universitario de la Costa Sur (CUC Sur), Universidad de Guadalajara. Avenida Independencia Nacional No. 151, Colonia Centro, Autlán de Navarro 48900, Jalisco, México. ${ }^{5}$ Centro de Investigación en Ciencias Biológicas Aplicadas (CICBA), Universidad Autónoma del Estado de México. Instituto literario No 100, Colonia Centro, Toluca 50000, Estado de México, México.

\section{Received: 1 July 2016 Accepted: 17 November 2016} Published online: 23 November 2016

\section{References}

1. Perfecto I, Vandermeer J. Coffee agroecology: A new approach to understanding agricultural biodiversity, ecosystem services and sustainable development. New York: Routledge; 2015.

2. Chappell MJ, Wittman H, Bacon CM, Ferguson BG, Barrios LG, Barrios RG, Jaffe D, Lima J, Mendéz E, Soto-Pinto L, Vandermeer J, Perfecto I. Food sovereignty: An alternative paradigm for poverty reduction and biodiversity conservation in Latin America. F1000 Res. 2013:2:235.

3. FAO. El estado mundial de la agricultura y la alimentación. Roma: Organización de las Naciones Unidas para la Alimentación y la Agricultura; 2015.

4. Naranjo S. Enabling food sovereignty and a prosperous future for peasants by understanding the factors that marginalise peasants and lead to poverty and hunger. Agric Hum Values. 2012;29(2):231-46.

5. Via Campesina. Food sovereignty: A future without hunger. Statement by the NGO Forum to the World food summit, NGO Forum to the world food summit. 1996. https://viacampesina.org/en/. Accessed Aug 2015.

6. Harvey CA, Komar O, Chazdon R, Ferguson BG, Finegan B, Griffith DM, SotoPinto L. Integrating agricultural landscapes with biodiversity conservation in the Mesoamerican hotspot. Conserv Biol. 2008:22(1):8-15.

7. Altieri MA, Toledo VM. Natural resources management among small-scale farmers in semiarid lands: Building on traditional knowledge and agroecology. Ann Arid Zone. 2005;44:365-85.

8. Mundial B. Indicadores de desarrollo mundial. 2015. http://datos. bancomundial.org/pais/México. Accessed 18 Aug 2015.

9. CONEVAL. Medición de la pobreza en México. Ciudad de México: Consejo Nacional de Evaluación de la Política en México; 2012.

10. Mundo-Rosas V, Shamah-Levy T, Rivera-Dommarco JA. Epidemiología de la inseguridad alimentaria en México. Salud Publica Mex. 2013;55(2):206-13.

11. Boege E. El patrimonio biocultural de los pueblos indígenas de México: Hacia la conservación in situ de la biodiversidad y agrodiversidad en los territorios indígenas. Ciudad de México: Instituto Nacional de Antropología e Historia; 2008

12. Casas A, Camou A, Otero-Arnaiz A, Rangel-Landa S, Cruse-Sanders J, Solís L, Torres I, Delgado A, Moreno-Calles Al, Vallejo M, Guillén S, Blancas J, Parra F, Farfán-Heredia B, Aguirre-Dugua X, Arellanes Y, Pérez-Negrón E. Manejo tradicional de biodiversidad y ecosistemas en Mesoamérica: el Valle de Tehuacán. Investigación ambiental Ciencia y Política Pública. 2014;6:23-44.

13. Toledo VM, Barrera-Bassols N. La memoria biocultural. La importancia ecológica de las sabidurías tradicionales. Barcelona: Icaria Editorial; 2008.

14. Moreno-Calles Al, Alejandro C, Toledo VM, Vallejo-Ramos M, editors. Etnoagroforestería en México. ENES-UNAM, IIES-UNAM. México: Morelia; 2016.

15. Casas A, Caballero J, Mapes C, Zárate S. Manejo de la vegetación, domesticación de plantas y origen de la agricultura en Mesoamérica. Bol Soc Bot Méx. 1997;61:31-47.

16. Casas A, Otero-Arnaiz A, Pérez-Negrón E, Valiente-Banuet A. In situ management and domestication of plants in Mesoamerica. Ann Bot. 2007; 100:1101-15

17. Moreno-Calles Al, Toledo VM, Casas A. Los sistemas agroforestales tradicionales de México: Una aproximación biocultural. Botanical Sciences. 2013;91(4):375-98

18. Moreno-Calles Al, Galicia Luna V, Casas A, Toledo-Manzur VM, Vallejo M, Santos -Fita D, Camou A. La Etnoagroforestería: El estudio de los sistemas agroforestales tradicionales de México. Revista Etnobiología. 2014;12(3):1-16.

19. Moreno-Calles Al, Toledo V, Casas A. Importancia biocultural de los sistemas agroforestales tradicionales de México. In: Olive L, Lazos-Ramírez L, editors. Hacia un modelo intercultural de sociedad del conocimiento en México.
Ciudad de México: Universidad Nacional Autónoma de México. México; 2014. p. 35-56.

20. Nair PR, Viswanath S, Lubina PA. Cinderella agroforestry systems. Agrofor Syst. 2016;90:1-17.

21. Perfecto I, Vandermeer J, Wright A. Nature's matrix. Linking agriculture conservation and food sovereignty. New York: Taylor and Francis Group; 2009.

22. Instituto Nacional de Estadística, Geografía e Informática. Catálogo único de claves de áreas geoestadísticas, estatales, municipales y localidades consulta y descarga. 2015.

23. Galluzzi GPE, Negri V. Home gardens: neglected hotspots of agrobiodiversity and cultural diversity. Biodivers Conserv. 2010;19(13):3635-54.

24. Kumar BM, Nair PK. The enigma of tropical homegardens. Agrofor Syst. 2004;61(1-3):135-52.

25. Caballero J, Cortés L, Martínez-Balleste A. El manejo de la biodiversidad en los huertos familiares. In: Toledo VM, editor. La biodiversidad de México. Inventarios, manejos, usos, informática, conservación e importancia cultural. Ciudad de México: Fondo de Cultura Económica, Consejo Nacional para la Cultura y las Artes; 2010. p. 220-34.

26. Guido S. Los huertos familiares de Mesoamérica. Mérida: Universidad Autónoma de Yucatán; 2012

27. Guido S. Los huertos familiares de la Península de Yucatán. Mérida: Universidad Autónoma de Yucatán; 2012.

28. Guido S. Diversidad florística, usos, y origen del material genético de las especies de los huertos familiares de la Península de Yucatán. In: El huerto familiar del sureste de México. Tabasco: El Colegio de la Frontera Sur y Secretaría de Energía, Recursos Naturales y Protección Ambiental; 2012. p. 7-97.

29. Mariaca-Méndez R. La complejidad del huerto familiar maya del sureste de México. In: Mariaca- Méndez R, editor. El huerto familiar del sureste de México. Villahermosa: El Colegio de la Frontera Sur y Secretaría de Energía, Recursos Naturales y Protección Ambiental; 2012. p. 7-97.

30. Wiersum KF. Forest gardens as an "intermediate" land-use system in the nature-culture continuum: characteristics and future potential. Agrofor Syst. 2004;61:123-34

31. Gómez-Pompa A, Flores-Guido JS, Sosa V. El pet kot: Una selva tropical creada por los mayas. In: Guido S, editor. Los huertos familiares de Mesoamérica. Mérida: Universidad Autónoma de Yucatán; 2012.

32. Alcorn JB. Development policy, forests, and peasant farms: reflections on Huastec-managed forests' contributions to commercial production and resource conservation. Econ Bot. 1984;38(4):389-406.

33. Martínez-Alfaro MA, Evangelista V, Basurto F, Mendoza M, Cruz-Rivas A. Flora útil de los cafetales en la Sierra Norte de Puebla, México. Revista Mexicana de Biodiversidad. 2007;78(1):15-40

34. Kleinman PJ, Pimentel AD, Bryant RB. The ecological sustainability of slashand-burn agriculture. Agric Ecosyst Environ. 1995:52(2):235-49.

35. Remmers GGA, Ucan E. La roza-tumba-quema maya: Un sistema agroecológico tradicional frente al cambio tecnológico. Etnoecológica. 1996:3:97-109.

36. Casas A, Viveros JL, Caballero J. Etnobotánica mixteca: sociedad, cultura y recursos naturales en la Montaña de Guerrero. México D.F: CONACULTA, Instituto Nacional Indigenista; 1994.

37. Barrera-Cristóbal H. Tlacolol: Sistema agroforestal del trópico seco. Bachellor Dissertation. Texcoco: Universidad Autónoma Chapingo; 1999.

38. Terán S, Rasmussen C. La milpa de los mayas: La agricultura de los mayas prehispánicos y actuales del noroeste de Yucatán. Mérida: Gobierno del Estado de Yucatán; 1994

39. Toledo VM, Barrera-Bassols N, García-Frapolli E, Alarcón-Chaires P. Uso múltiple y biodiversidad entre los Mayas yucatecos. Interciencia. 2008;33:345-52.

40. Rubio E, Rodríguez G. El mawechi y otras estrategias agropecuarias tradicionales de la familia raramuri en la Sierra Tarahumara. Actas Iberoamericanas de Conservación Animal. 2014;4:175-7.

41. Chávez BC. Coamil, un sistema de producción-agrícola tradicional en Jalisco. Guadalajara: Ph. D. Dissertation. Universidad de Guadalajara; 1983.

42. Cedeño-Benavidez M. Coamil un sistema de producción agrícola en el Ejido la Yerbabuena en el estado de Colima. Bachelor Dissertation. Uruapan: Universidad Vasco de Quiroga; 1994.

43. Lambert DP. Crop diversity and fallow management in a tropical deciduous forest shifting cultivation system. Hum Ecol. 1996;24(4):427-53.

44. Cayetano M. Los hijos del maíz. Etnoagroecología de Zea maíz L. entre los ayuuk de Guichicovi en Oaxaca. Popayán Colombia: Congreso Latinoamericano de Etnobiología; 2015. 
45. Santos-Fita D, Naranjo EJ, Bello E, Estrada EIJ, Mariaca R, Macario PA. La milpa comedero-trampa como una estrategia de cacería tradicional maya. Estudios de Cultura Maya. 2013;42(42):87-118.

46. Bernice B. El desarrollo rural en México y la serpiente emplumada. Ciudad de México: Fondo de Cultura Económica, Centro de Investigación de Estudios Avanzados, Instituto Politécnico Nacional; 2010.

47. Colunga García-Marín P. Variación morfológica, manejo agrícola y grados de domesticación de Opuntia spp. en el Bajío Guanajuatense. Master's Thesis. Texcoco: Colegio de Posgraduados; 1984.

48. Palerm JV. La persistencia y expansión de sistemas agrícolas tradicionales: El caso del huamil en el Bajío mexicano. Monografías del Jardín Botánico de Córdoba. 1997:5:121-33.

49. Moreno-Calles Al, Casas A, Blancas J. Agroforestry systems and biodiversity conservation in arid zones: the case of the Tehuacán-Cuicatlán Valley, Central México. Agrofor Syst. 2010;80:315-31.

50. Moreno-Calles Al, Casas A, Torres I, García-Frapolli E. Traditional agroforestry systems of multi-crop "milpa" and "chichipera" cactus forest in the arid Tehuacán Valley, México: their management and role in people's subsistence. Agrofor Syst. 2012;84:207-26.

51. Campos N. Conservación de biodiversidad en sistemas agroforestales de matorrales rosetófilos y palmares del Valle de Tehuacán. Master's Thesis. Ciudad de México: Universidad Nacional Autónoma de México; 2015.

52. Vallejo-Ramos M, Casas A, Pérez-Negrón E, Moreno-Calles Al, Hernández Ordoñez O, Téllez O, Dávila P. Agroforestry systems of the lowland alluvial valleys of the Tehuacán-Cuicatlán Biosphere Reserve: an evaluation of their biocultural capacity. J Ethnobiol Ethnomed. 2015;11:8.

53. Hoosgester van Dijk V, Casas A, Moreno-Calles Al. Tajos de la Sierra Gorda Guanajuatense: Sistemas agroforestales de importancia ecológica, económica y cultural. In: Moreno-Calles Al, Casas A, Toledo VM, VallejoRamos M, editors. Etnoagroforestería en México. Morelia: Escuela Nacional de Estudios Superiores Unidad Morelia, Instituto de Investigaciones en Ecosistemas y Sustentabilidad; 2016

54. Cariño-Olvera M. Evocando al edén: conocimiento, valoración y problemática del oasis de los Comundú. Barcelona: Icaria Editorial; 2013.

55. Fortanelli J, Loza JG, Carlín F, Aguirre JR. Jardines en el desierto. Agricultura de riego, tradicional y moderna en el altiplano potosino. San Luis Potosí: Universidad Autónoma de San Luis Potosí, Consejo Potosino de Ciencia y Tecnología; 2007.

56. Larios C, Casas A, Vallejo M, Moreno-Calles Al, Blancas J. Plant management and biodiversity conservation in nahuatl homegardens of the Tehuacán Valley, México. J Ethnobiol Ethnomed. 2013;9:74

57. Arellanes Y, Casas A, Arellanes A, Vega E, Blancas J, Vallejo M, Torres I, Rangel Landa S, Moreno-Calles Al, Solís L, Peréz-Negrón E. Influence of traditional markets and interchange on plant management in the Tehuacan Valley. J Ethnobiol Ethnomed. 2013;9:38.

58. Ramos-Elorduy J, Moreno JM, Vázquez Al, Landero I, Oliva-Rivera H, Camacho VH. Edible Lepidoptera in México: Geographic distribution, ethnicity, economic and nutritional importance for rural people. J Ethnobiol Ethnomed. 2011;7(1):1-22.

59. Donkin RA. Agricultural terracing in the aboriginal new world. Tucson: Wenner-Green Foundation for Anthropological Research, University Arizona Press; 1979

60. Rojas-Rabiela T. La agricultura en la época prehispánica. In: Rojas-Rabiela T, editor. La agricultura en tierras mexicanas desde sus orígenes hasta nuestros días. Ciudad de México: Comisión Nacional para la Cultura y las Artes, Grijalbo S.A. de C.V; 1991.

61. Altieri MA, Trujillo J. The agroecology of corn production in Tlaxcala, México. Hum Ecol. 1987;15:189-220

62. Mountjoy DC, Gliessman SR. Traditional management of a hillside agroecosystem in Tlaxcala, México: An ecologically based maintenance system. Am J Altern Agric. 1988;3(01):3-10.

63. González-Jácome A. Historias varias: Un viaje en el tiempo con los agricultores mexicanos. Ciudad de México: Universidad Iberoamericana; 2011.

64. Magdaleno ML, García ME, Valdés-Hernández Jl, de la Cruz IV. Evaluación del sistema agroforestal "árboles en terrenos de cultivo" en Vicente Guerrero, Tlaxcala, México. Rev Fitotec Mex. 2005;28:203-12.

65. Renard D, Iriarte J, Birk JJ, Rostain S, Glaser B, McKey D. Ecological engineers ahead of their time: The functioning of pre-Columbian raised-field agriculture and its potential contributions to sustainability today. Ecol Eng. 2012;45:30-44.
66. González-Jácome A. Humedales en el suroeste de Tlaxcala: Agua y agricultura en el siglo XX. Ciudad de México: Universidad Iberoamericana; 2008.

67. Pérez-Sánchez JM. El manejo de los recursos naturales bajo el modelo agrícola de camellones chontales en Tabasco. Revista de Ciencias Sociales de la Universidad Iberoamericana. 2008;2(4):1-9.

68. Rojas Rabiela T. La agricultura chinampera: Compilación histórica. Texcoco: Universidad Autónoma Chapingo; 1993.

69. Altieri MA. Agroecology, small farms and food sovereignty. Mon Rev. 2009; 61(3):102.

70. Huai $\mathrm{H}$, Hamilton A. Characteristics and functions of traditional homegardens: a review. Frontiers of Biology in China. 2009;4(2):151-7.

71. Kuhlein HV. How ethnobiology can contribute to food security. J Ethnobiol. 2014;32(1):12-27.

72. Aguilar-Støen M, Moe SR, Camargo-Ricalde SL. Home gardens sustain crop diversity and improve farm resilience in Candelaria Loxicha, Oaxaca, México. Hum Ecol. 2009;37:55-77.

73. Perfecto I, Vandermeer J. Biodiversity conservation in tropical agroecosystems: A new conservation paradigm. Annals New York Academic Science. 2008;1134:173-200.

74. Mintz SW. Dulzura y poder: el lugar del azúcar en la historia moderna. Ciudad de México: Editorial Siglo xxi; 1996.

75. Instituto Nacional de Estadística, Geografía e Informática. Censo Ejidal 2007. Ciudad de México: INEGl; 2008.

76. Instituto Nacional de Estadística, Geografía e Informática. Censo Nacional de Población y Vivienda 2010. Ciudad de México: INEGI; 2010.

77. Wittman H, Desmarais AA, Wiebe N, editors. Food sovereignty: reconnecting food, nature and community. Canada: Fernwood Publising; 2010.

78. Toledo VM, Garrido D, Barrera-Bassols N. The struggle for life socioenvironmental conflicts in México. Lat Am Perspect. 2015;204(42):133-47.

79. Boege E, Carranza T. Agricultura sostenible campesino-indígena, soberanía alimentaria y equidad de género. In: Seis experiencias de organizaciones indígenas y campesinas en México. Ciudad de México: Programa de Intercambio, Diálogo y Asesoría en Agricultura Sostenible y Soberanía Alimentaria; 2009.

80. Fairbairn M. Framing resistance: International food regimes and the roots of food sovereignty. In: Wittman H, Desmarais AA, Wiebe N, editors. Food sovereignty: reconnecting food, nature and community. Canada: Fernwood Publising; 2010.

81. Bauman Z. Vidas desperdiciadas: la modernidad y sus parias. Buenos Aires: Paidós; 2005.

82. Godfray HCJ, Beddington JR, Crute IR, Haddad L, Lawrence D, Muir JF, Toulmin C. Food security: The challenge of feeding 9 billion people. Science. 2010;327:812-8.

83. Rozzi R, Pickett ST, Palmer C, Armesto JJ, Callicott JB. Linking ecology and ethics for a changing world. New York: Springer; 2013.

84. Glamann J, Hanspach J, Abson DJ, Collier N, Fischer J. The intersection of food security and biodiversity conservation: A review. Regional Environmental Chance. 2015:1-11. doi:10.1007/s10113-015-0873-3.

85. Holt-Gimenez E, Altieri MA. Agroecology, food sovereignty, and the new green revolution. Agroecology and Sustainable Food Systems. 2013;37(1):90-102.

86. Casas A, Viveros JL, Katz E, Caballero J. Las plantas en la alimentación mixteca: una aproximación etnobotánica. Am Indig. 1987;47(2):317-43.

87. Appendini K, Barrios RG, De La Tejera B. Seguridad alimentaria y calidad de alimentos: ¿Una estrategia campesina? Revista Europea de Estudios Latinoamericanos y del Caribe. 2003:65-83.

88. Gillespie AR, Bocanegra-Ferguson DM, Jimenez-Osornio JJ. The propagation of Ramón (Brosimum alicastrum SW.; Moraceae) in Mayan homegardens of the Yucatan peninsula of México. New For. 2004;27(1):25-38. 